\title{
Simvastatin delays castration-resistant prostate cancer metastasis and androgen receptor antagonist resistance by regulating the expression of caveolin-1
}

\author{
YINGYING GAO ${ }^{1,2}$, LUO LI $^{1}$, TING LI ${ }^{1}$, LEI MA ${ }^{3}$, MENGJUAN YUAN ${ }^{4,5}$, WEI SUN ${ }^{4,5}$, HONG LIN CHENG ${ }^{4}$, \\ LINGFANG NIU $^{1}$, ZHONGBO DU ${ }^{4}$, ZHEN QUAN $^{4}$, YANRU FAN $^{1}$, JIAXIN FAN ${ }^{1}$, \\ CHUNLI LUO $^{1}$ and XIAOHOU WU ${ }^{4}$ \\ ${ }^{1}$ Department of Laboratory Diagnosis, Chongqing Medical University, Chongqing 408000; \\ ${ }^{2}$ Department of Laboratory Diagnosis, Clinical Medical College, Jiamusi University; ${ }^{3}$ Department of Laboratory Diagnosis, \\ The First Affiliated Hospital of Jiamusi University, Jiamusi, Heilongjiang 154000; ${ }^{4}$ Department of Urology, \\ The First Affiliated Hospital of Chongqing Medical University; ${ }^{5}$ Department of Urology, \\ Fuling Center Hospital of Chongqing City, Chongqing 408000, P.R. China
}

Received November 27, 2018; Accepted March 22, 2019

DOI: 10.3892/ijo.2019.4774

\begin{abstract}
The failure of androgen deprivation therapy in prostate cancer treatment mainly results from drug resistance to androgen receptor antagonists. Although an aberrant caveolin-1 (Cav-1) expression has been reported in multiple tumor cell lines, it is unknown whether it is responsible for the progression of castration-resistant prostate cancer (CRPC). Thus, the aim of the present study was to determine whether Cav-1 can be used as a key molecule for the prevention and treatment of CRPC, and to explore its mechanism of action in CRPC.For this purpose, tissue and serum samples from patients with primary prostate cancer and CRPC were analyzed using immunohistochemistry and enzyme-linked immunosorbent assay, which revealed that Cav-1 was overexpressed in CRPC. Furthermore, Kaplan-Meier survival analysis and univariate Cox proportional hazards regression analysis demonstrated that Cav-1 expression in tumors was an independent risk factor for the occurrence of CRPC and was associated with a shorter recurrence-free survival time in patients with CRPC. Receiver operating characteristic curves suggested that serum Cav-1 could be used as a diagnostic biomarker for CRPC (area under the curve, 0.876) using a cut-off value of $0.68 \mathrm{ng} / \mathrm{ml}$ (with a sensitivity of $82.1 \%$ and specificity of $80 \%$ ). In addition, it was determined that Cav-1 induced the invasion and migration of CRPC cells by the activation of the $\mathrm{H}-\mathrm{Ras} /$ phosphoinositide-specific phospholipase $\mathrm{C} \varepsilon$ signaling
\end{abstract}

Correspondence to: Professor Chunli Luo, Department of Laboratory Diagnosis, Chongqing Medical University, 1 Medical College Road, Yuzhong, Chongqing 408000, P.R. China

E-mail: luochunli79@126.com

Key words: simvastatin, caveolin-1, Ras, phosphoinositide-specific phospholipase $\mathrm{C} \varepsilon$, castration-resistant prostate cancer, metastasis, drug resistance cascade in the cell membrane caveolae. Importantly, simvastatin was able to augment the anticancer effects of androgen receptor antagonists by downregulating the expression of Cav-1. Collectively, the findings of this study provide evidence that Cav-1 is a promising predictive biomarker for CRPC and that lowering cholesterol levels with simvastatin or interfering with the expression of Cav-1 may prove to be a useful strategy with which to prevent and/or treat CRPC.

\section{Introduction}

Androgen deprivation therapy (ADT) is considered a milestone in the treatment of advanced prostate cancer. Although the majority of cases of prostate cancer initially exhibit an apparently good response to ADT, almost all treatments eventually fail and the disease progresses to metastatic castration-resistant prostate cancer (CRPC), which is the leading cause of mortality (1-3). Recently, several novel agents, such as the second-generation androgen receptor (AR) antagonist, enzalutamide, have been administered to patients and are considered to have better therapeutic effects than conventional AR antagonists, such as bicalutamide and flutamide (4-8). However, the majority of patients become resistant to all these agents within a few years. To date, several molecular mechanisms have been implicated in the progression of castration resistance, the majority of which are associated with the AR signaling axis, involving AR amplification, mutations, coregulators, activation, aberrant post-translational modification and alternative splicing $(1,7,9,10)$. However, it remains unclear as to whether other signaling pathways contribute to resistance or can be targeted, and if so, which ones and to what extent.

Caveolin-1 (Cav-1) is a scaffold protein of caveolae, which are 50-100 $\mathrm{nm} \Omega$-shaped invaginations of the plasma membrane in the majority of cell types (11). Previous studies have demonstrated that Cav-1 is involved in the regulation of cholesterol homeostasis and interacts with multiple signaling 
molecules, including small GTPases, Src tyrosine kinases and endothelial nitric oxide synthase $(11,12)$. Numerous studies have also demonstrated that Cav-1 is overexpressed in numerous human tumors and is associated with poor clinical outcomes (13-15). However, the tumorigenic effects of Cav-1 in various types of cancer at different stages are controversial (16). Although Hehlgans and Cordes also reported that radio- and chemoresistance were associated with increased Cav-1 levels in certain types of cancer (17), the effects of Cav-1 on the progression from primary prostate cancer (PPC) to CRPC remain largely unknown.

Phosphoinositide-specific phospholipase Ce (PLCE), the homolog of C. elegans PLC210, is a member of the human phosphatidylinositol PLC family. PLCE is unique compared with other phospholipase $\mathrm{C}$ isoforms in terms of its $\mathrm{N}$-terminal GTP exchange factor (GRF CDC25-like) domain and two C-terminal Ras-associating (RA) domains, which reveals that it functions by activating Ras family GTPases, and is also able to be regulated by Ras family GTPases (18). Ras oncogenes are involved in a high proportion of cancer types (19). However, the mechanisms through which the Ras direct signaling effector, PLC $\varepsilon$, contributes to tumor development and is associated with Ras in this context, have not yet been elucidated. It has been demonstrated that PLC $\varepsilon$ contributes to carcinogenesis in different types of tumors (20). Consistent with these data, our previous studies revealed that PLCe expression was significantly higher in urologic neoplasms and promoted AR nuclear translocation in prostate cancer $(21,22)$. However, further studies are required to determine whether the Ras/PLC $\varepsilon$ signaling pathway regulates malignant progression and drug resistance in CRPC and to elucidate the underlying mechanisms of action.

The aim of the present study was to examine whether Cav-1 plays a key role in regulating metastasis and sensitization to AR antagonists through the Ras/PLC $\varepsilon$ signaling cascade, resulting in the development of CRPC, and whether the downregulation of the expression of Cav-1 using cholesterol inhibitors can suppress this lethal progression. For this purpose, a comprehensive analysis was conducted using tissue and serum specimens from patients with PPC and CRPC, as well as different cell lines in vitro to determine treatment strategies using cellular models. Taken together, the findings of this study may contribute to the clarification of the critical biological pathways involved in metastatic CRPC and may aid in the development of novel strategies for the prevention and treatment of CRPC.

\section{Materials and methods}

Serum and tissue samples. A total of 70 PPC and 56 CRPC serum samples were collected from patients prior to surgery between December, 2016 and August, 2018, and 45 PPC and 36 CRPC tissue samples were collected from patients between January, 2010 and August, 2018 at The First Affiliated Hospital of Chongqing Medical University, Chongqing, China. All the participants were informed of the aims and procedures of the study. Patients with CRPC were selected according to the European Association of Urology (EAU) guidelines (23). The present study retrospectively collected clinical data, such as age, prostate-specific antigen (PSA) levels and metastatic status from medical records. The study was approved by the Ethics Committee of Chongqing Medical University and was conducted according to the principles of the Declaration of Helsinki.

Immunohistochemistry assay. All tissue samples were fixed in $10 \%$ paraformaldehyde for $12 \mathrm{~h}$ at $25^{\circ} \mathrm{C}$. They were then embedded in paraffin and cut into $5-\mu \mathrm{m}$-thick sections. Immunohistochemical staining was detected using a standard immunoperoxidase staining procedure. The sections were incubated overnight at $4^{\circ} \mathrm{C}$ with anti-Cav-1, (1:200, cat. no. 3267; Cell Signaling Technology, Inc., Danvers, MA, USA) or anti-H-Ras (1:50, cat. no. sc-53958), anti-K-Ras (1:50, cat. no. sc-521), anti-PLCE (1:50, cat. no. sc-28402) (all from Santa Cruz Biotechnology, Inc., Dallas, TX, USA), followed by incubation with a secondary antibody (1:100, SP9000 or PV9003; ZSGB-BIO, Beijing, China) at $37^{\circ} \mathrm{C}$ for $1 \mathrm{~h}$, then sequentially incubated with avidin-biotin complex solution (room temperature, $1 \mathrm{~h}$ ). Protein expression was detected by coloration with diaminobenzidine (DAB) (ZLI-9018; ZSGB-BIO) buffer for $5 \mathrm{~min}$, and the sections were counterstained with hematoxylin for $5 \mathrm{~min}$ at room temperature. All images were captured using a fluorescent microscope (Nikon Corp., Tokyo, Japan). The staining intensity was scored as follows: 0 (no staining), 1 (light staining), 2 (moderate staining) and 3 (strong staining). The immunoreactivity ratio was scored as follows: 0 ( $0 \%$ immunoreactive cells), $1(<5 \%$ immunoreactive cells), 2 (5-50\% immunoreactive cells) and 3 ( $>50 \%$ immunoreactive cells). The final score was defined as the sum of both parameters. Scores $\leq 2$ denoted a negative expression, while scores $\geq 3$ denoted a positive expression.

Enzyme-linked immunosorbent assay (ELISA). Serum samples were centrifuged at $1,000 \mathrm{x}$ g for $10 \mathrm{~min}$ (room temperature) and stored at $-80^{\circ} \mathrm{C}$ until analysis. The concentrations of Cav-1 were determined using a human Cav-1 ELISA kit (detection range, $0.15-10 \mathrm{ng} / \mathrm{ml}$; Signalway Antibody LLC, College Park, MD, USA), according to the manufacturer's instructions. The absorbance was measured at a wavelength of $450 \pm 2 \mathrm{~nm}$ to detect the concentration of Cav-1 in serum using a microplate reader (Bio-Rad Laboratories, Inc., Hercules, CA, USA).

Cells, cell culture and treatment. The human prostate cancercell lines, LNCaP (CRL-1740 $\left.{ }^{\mathrm{TM}}\right)$, PC3 (CRL-1435 ${ }^{\mathrm{TM}}$ ) and DU145 (HTB- $81^{\mathrm{TM}}$ ), were obtained from the American Type Culture Collection (ATCC, Manassas, VA, USA). Castration-resistant derivatives of LNCaP cells [specifically, bicalutamide-resistant cells (Bic-R) and enzalutamide-resistant cells (En-R)] were constructed and maintained as previously described (24). All cells were cultured in RPMI-1640 medium (Thermo Fisher Scientific, Inc., Waltham, MA, USA) containing $1 \%$ penicillin and streptomycin antibiotics (Beyotime Institute of Biotechnology, Haimen, China) and $10 \%$ fetal bovine serum (Thermo Fisher Scientific, Inc.) at $37^{\circ} \mathrm{C}$ in a humidified atmosphere of $5 \% \mathrm{CO}_{2}$.

For transfection, $1 \times 10^{5}$ cells were seeded in a 6-well plate and passaged every 2 days. When appropriate, i.e., at 1 day after seeding or when the cell cultures were $40-60 \%$ confluent, the cells were transfected with $4 \mu \mathrm{g}$ Cav-1 knockdown plasmids or negative control (Shanghai GenePharma Co., Ltd., 
Shanghai, China) and $10 \mu 1$ Lipofectamine 2000 (Thermo Fisher Scientific, Inc.) in serum-free medium, according to the manufacturer's instructions. The transfection medium was replaced with fresh culture medium after $6-8 \mathrm{~h}$ at $37^{\circ} \mathrm{C}$. The transfection process of the $\mathrm{H}-\mathrm{Ras} \mathrm{G} 12 \mathrm{~V}$ or K-RasG12V plasmids (Shanghai GenePharma Co., Ltd.) was similar to that of the Cav-1 knockdown plasmids. However, for the transduction of PLC $\varepsilon$ knockdown lentiviral particles, $1 \times 10^{5}$ cells were seeded in 6-well plates and incubated with $3 \mathrm{ml}$ complete medium until 40-60\% confluency, and subsequently $3 \mu$ of PLC $\varepsilon$ knockdown lentivirus or negative control lentivirus (Shanghai GenePharma Co., Ltd.) and $3 \mathrm{ml}$ of Polybrene (Thermo Fisher Scientific) were added to the culture medium for $8 \mathrm{~h}$. The original medium was then replaced with $6 \mathrm{ml}$ fresh medium containing $1 \mu \mathrm{g} / \mathrm{ml}$ puromycin. The cells were harvested after $72 \mathrm{~h}$ and used for protein extraction, or were cultured for $48 \mathrm{~h}$ and used for RNA extraction or in other experiments.

Reverse transcription-quantitative polymerase chain reaction $(R T-q P C R)$. RNA was extracted from all cell lines using TRIzol reagent, and $1 \mu \mathrm{gRNA}$ was reverse transcribed into complementary DNA using the Prime Script ${ }^{\mathrm{TM}}$ RT reagent kit, according to the manufacturer's instructions (Takara Biotechnology Co., Ltd., Dalian, China). Messenger RNA (mRNA) levels were analyzed using the SYBR PremixEx Taq ${ }^{\mathrm{TM}}$ II kit (Takara Biotechnology Co., Ltd.) and the CFX96 ${ }^{\mathrm{TM}}$ Real-Time PCR Detection System (Bio-Rad Laboratories, Inc., Hercules, CA, USA). The thermocycling conditions were as previously described (24), with the exception of the annealing temperature. For Cav-1 analysis, the annealing temperature was $52^{\circ} \mathrm{C}$, while for $\mathrm{H}-\mathrm{RasG} 12 \mathrm{~V}$ and $\mathrm{K}-\mathrm{RasG} 12 \mathrm{~V}$ analysis, the annealing temperature were $56^{\circ} \mathrm{C}$ and $60^{\circ} \mathrm{C}$. The mRNA expression levels were calculated using the comparative $2^{-\triangle \Delta C q}$ method (25) and GAPDH was used as a calibrator. The primers used for the human Cav-1, H-RasG12V, K-RasG12V and GAPDH genes were as follows: Cav-1 (107 bp), forward (F), 5'-CATCCCGATGGCACTCATCTG-3' and reverse (R), 5'-TGCACTGAATCTCAATCAGGAAG-3'; H-RasG12V (129 bp), F, 5'-CTGAGGAGCGATGACGGAA-3' and R, 5'-AGGCTCACCTCTATAGTGGG-3'; K-RasG12V (165 bp), F, 5'-AAGGCCTGCTGAAAATGACTG-3' and R, 5'-GGTCCTGCACCAGTAATATGCA-3'; and GAPDH (258 bp), F, 5'-AGAAGGCTGGGGCTCATTTG-3', R, 5'-AGGGGCCAT CCACAGTCTTC-3'.

Reagents and treatment. Simvastatin (S1792; Selleck Chemicals, Houston, TX, USA) was activated using absolute ethanol and adjusted to a final concentration of $10 \mathrm{mM}$ with PBS (pH 7.2). Methyl- $\beta$-cyclodextrin (M- $\beta$-CD; C4555; Sigma-Aldrich; Merck KGaA, Darmstadt, Germany) was solubilized to $30 \mathrm{mM}$ in PBS. Cholesterol (C3045; Sigma-Aldrich; Merck KGaA) was solubilized to $10 \mathrm{mM}$ in ethanol. All these procedures were performed according to the manufacturer's instructions and the reagents were stored at $-20^{\circ} \mathrm{C}$.

Western blot analysis. Total protein extraction and subcellular fractionations were performed as previously described $(26,27)$, although certain modifications were introduced to extract the detergent-resistant fraction (DRF) from lipid-rich membranes and the detergent-soluble fraction (DSF). Cell pellets were lysed in $1 \%$ Triton X-100, $25 \mathrm{mM}$ Tris (pH 8.0), $150 \mathrm{mM} \mathrm{NaCl}$,
10 mM Na-pyrophosphate, $10 \mathrm{mM}$ NaF, 3 mM EDTA, $1 \mathrm{mM}$ Phenylmethanesulfonyl fluoride (PMSF), $10 \mu \mathrm{g} / \mathrm{ml}$ aprotinin, $1 \mathrm{mM}$ benzamidine and $1 \mathrm{mM}$ sodium orthovanadate for $10 \mathrm{~min}$ at $4^{\circ} \mathrm{C}$. An ultrasonic homogenate step was included to more finely disrupt cellular membranes, and the homogenate was incubated for $30 \mathrm{~min}$ on ice and then centrifuged at $100,000 \mathrm{xg}$ for $30 \mathrm{~min}$ at $4^{\circ} \mathrm{C}$. The insoluble pellets (containing the DRF) and the supernatant (containing the DSF) were resuspended by boiling in SDS-PAGE sample buffer.

Western blot analysis was performed as previously described $(24,28)$. The intensity analyses were quantified using Image-Pro Plus 6.0 software. The membranes were incubated with primary antibodies overnight at $4^{\circ} \mathrm{C}$, then sequentially incubated with secondary antibodies for $2 \mathrm{~h}$ at room temperature. The primary and secondary antibodies used were as follows: Anti-Cav-1 (1:1,000, cat. no. 3267), anti-matrix metalloproteinase 2 (MMP2) (1:1,000, cat. no. 40994), anti-matrix metalloproteinase 9 (MMP9) (1:1,000, cat. no. 13667), anti-Snail (1:1,000, cat. no. 3879) and anti-GAPDH (1:1,000, cat. no. 5174) antibodies were obtained from Cell Signaling Technology. Anti-H-Ras (1:500, cat. no. sc-53958), anti-K-Ras (1:500, cat. no. sc-521), anti-3-hydroxy-3-methylglutaryl coenzyme A (HMG-CoA) reductase (HMGR) (1:500, cat. no. sc-271595) and anti-PLCE (1:500, cat. no.sc-28402) antibodies were obtained from Santa Cruz Biotechnology. Goat anti-mouse $\operatorname{IgG}(1: 3,000$, cat. no. SA00001-1), goat anti-rabbit IgG (1:3,000, cat. no. SA00001-2) and rabbit anti-goat $\operatorname{IgG}(1: 3,000$, cat. no. SA00001-4) were obtained from ProteinTech (Rosemont, IL, USA).

Cell Counting kit-8 (CCK-8) assay. The cells (2,000 cells/well) examined for cell viability using the CCK-8 assay were seeded in a 96-well plate and incubated for $12 \mathrm{~h}$ at $37^{\circ} \mathrm{C}$. Following 24-72 $\mathrm{h}$ of treatment with various agents or concentrations, CCK-8 reagent solution (10 $\mu \mathrm{l}$; Beyotime Institute of Biotechnology) was added to each well followed by incubation for $2 \mathrm{~h}$ at $37^{\circ} \mathrm{C}$. The absorbance was measured at $450 \mathrm{~nm}$ using a microplate reader (Bio-Rad Laboratories, Inc.). Cell viability data were calculated as percentage values for each treatment condition compared with the control. The synergistic effects of simvastatin and AR antagonists was calculated using CalcuSyn ${ }^{\circledR}$ software version 2.0 (Biosoft, Cambridge, UK), and the combination index (CI) quantitatively depicted additive effects $(\mathrm{CI}=1)$, synergism $(\mathrm{Cl}<1)$ or antagonism $(\mathrm{CI}>1)$.

Transwell and wound-healing assays. For the invasion assay, the cells $\left(1 \times 10^{4}\right.$ cells/well) incubated in serum-free medium were added to the upper chamber of the insert with Matrigel (BD Biosciences, San Jose, CA, USA). Following incubation at $37^{\circ} \mathrm{C}$ for $24 \mathrm{~h}$, permeable cells were fixed with $4 \%$ paraformaldehyde for $20 \mathrm{~min}$ and stained with $0.1 \%$ crystal violet for $10 \mathrm{~min}$ at room temperature. The cells were counted under an inverted microscope (Nikon Corp.) in 5 different visual fields and averaged.

For the wound-healing assay, the cells $\left(5 \times 10^{4}\right.$ cells/well) were seeded into 6-well plates and incubated in serum-free medium for $24 \mathrm{~h}$ at $37^{\circ} \mathrm{C}$. The cell monolayer was scratched with a $200-\mu 1$ pipette tip to form wound gaps. The cells were then washed in PBS and then incubated for $24 \mathrm{~h}$ at $37^{\circ} \mathrm{C}$ continuously, and images were captured under an inverted microscope (Nikon Corp.) at the indicated time-points. 
Table I. Demographic and clinical characteristics of the patients and the correlation of these characteristics with Cav-1 expression.

\begin{tabular}{|c|c|c|c|c|}
\hline \multirow[b]{2}{*}{ Characteristics } & \multirow[b]{2}{*}{ Overall } & \multicolumn{2}{|c|}{ Cav-1 } & \multirow[b]{2}{*}{ P-value } \\
\hline & & Negative (\%) & Positive (\%) & \\
\hline PPC & $\mathrm{n}=45$ & $31(68.9)$ & $14(31.1)$ & \\
\hline CRPC & $\mathrm{n}=36$ & $10(27.8)$ & $26(72.2)$ & \\
\hline Age of patients with PPC (years) & & & & $\mathrm{P}=0.650^{\mathrm{a}}$ \\
\hline Median & 66 & 66 & 67 & \\
\hline Quartiles (25-75) & $62-71$ & $62-70$ & $61-72$ & \\
\hline Age of patients with CRPC (years) & & & & $\mathrm{P}=0.794^{\mathrm{a}}$ \\
\hline Median & 72 & 71 & 72 & \\
\hline Quartiles (25-75) & $68-79$ & $67-77$ & $67-80$ & \\
\hline PSA of patients with PPC $(\mu \mathrm{g} / \mathrm{l})$ & & & & $\mathrm{P}=0.418^{\mathrm{a}}$ \\
\hline Median & 67.64 & 84.63 & 59.81 & \\
\hline Quartiles 25-75 & $26.91-463.00$ & 29.75-505.1 & 21.74-312.89 & \\
\hline PSA of patients with CRPC $(\mu \mathrm{g} / \mathrm{l})$ & & & & $\mathrm{P}=0.374^{\mathrm{a}}$ \\
\hline Median & 23.64 & 13.115 & 28.25 & \\
\hline Quartiles(25-75) & $5.99-47.76$ & $2.255-58.18$ & $8.05-46.39$ & \\
\hline \multicolumn{5}{|l|}{ Metastases in PPC } \\
\hline Bone & 17/45 (37.8) & $8 / 31(25.8)$ & 9/14 (64.3) & $\mathrm{P}=0.021^{\mathrm{b}}$ \\
\hline \multicolumn{5}{|l|}{ Metastases in CRPC } \\
\hline Bone & $27 / 36(75)$ & $4 / 10(40)$ & $23 / 26(88.5)$ & $\mathbf{P}=\mathbf{0 . 0 0 6}$ \\
\hline
\end{tabular}

${ }^{\mathrm{a}}$ Mann-Whitney test for 2 independent variables; ${ }^{\mathrm{b}} \mathrm{Chi}$-square for cohort study. Numbers in bold font indicate statistical significance $(\mathrm{P}<0.05)$. Cav-1, caveolin-1; PPC, primary prostate cancer; CRPC, castration-resistant prostate cancer; PSA, prostate-specific antigen.

Immunofluorescence staining. The cells $\left(1 \times 10^{5}\right.$ cells/well $)$ plated into 6-well plates covered with glass were incubated overnight at $37^{\circ} \mathrm{C}$. Once the cells adhered to the walls, they were fixed with $4 \%$ paraformaldehyde for $20 \mathrm{~min}$, the experiment was then performed as previously described (24). The cells were then incubated with the primary antibody (anti-Cav-1; 1:200; cat. no. 3267; Cell Signaling Technology, Inc.) overnight at $4^{\circ} \mathrm{C}$, and then with a secondary antibody (FITC conjugated goat anti-rabbit IgG, 1:100, ZF0311; ZSGB-BIO) in a dark room at $37^{\circ} \mathrm{C}$ for $30 \mathrm{~min}$. Cell nuclei were stained with DAPI (ZLI-9557; ZSGB-BIO) at $37^{\circ} \mathrm{C}$ for $5 \mathrm{~min}$. Immunofluorescence images were obtained upon incubation in 50\% glycerol using a fluorescence microscope (Nikon Corp.).

Statistical analysis. All experiments were repeated $\geq 3$ times independently with technical replicates and analyzed using SPSS software version 21.0 (IBM Corp., Armonk, NY, USA) and GraphPad Prism software version 5 (GraphPad Software, Inc., La Jolla, CA, USA). Significant differences among experimental groups were evaluated using the Student's t-test, one-way analysis of variance (ANOVA) and two-way ANOVA, while the Bonferroni adjustment was employed for multiple comparisons. Survival analyses were conducted using the Kaplan-Meier method. The Cox proportional hazards model was used to estimate hazard ratios (HRs). Other data were analyzed using Spearman's correlation analysis, the Chi-square test and Mann-Whitney test. One-way ANOVA was used for multiple comparisons followed by the Student-Newman-Keuls test as a post hoc test. A value of $\mathrm{P}<0.05$ was considered to indicate a statistically significant difference.

\section{Results}

Cav-1 is overexpressed in CRPC and is associated with genes in Ras signaling pathways. To determine the differential expression levels of Cav-1, H-Ras, K-Ras and PLC $\varepsilon$ in the tissues of patients with PPC and CRPC, and to explore the association between these proteins, 45 PPC and 36 CRPC tissue samples were collected from patients. Immunohistochemical assays revealed that the expression of Cav-1, H-Ras, K-Ras and PLC $\varepsilon$ was upregulated in the CRPC compared with the PPC tissue samples $(\mathrm{P}=0.002, \mathrm{P}=0.0272, \mathrm{P}=0.0377$ and $\mathrm{P}=0.0364$, respectively) (Fig. 1A and B). Spearman's correlation analysis revealed that there was a positive correlation between the Cav-1 expression levels and the H-Ras ( $\mathrm{r}=0.4151, \mathrm{P}=0.0118)$, K-Ras $(r=0.3443, P=0.0398)$ and PLC $\varepsilon$ expression levels $(r=0.4338, P=0.0082)$ in CRPC (Fig. 1C). The demographic and clinical characteristics of these patients and the association of these characteristics with Cav-1 expression are summarized in Table I. The data revealed that $72.2 \%(26 / 36)$ of the CRPC samples had a positive Cav-1 expression vs. $31.1 \%$ (14/45) of the PPC samples (Table I and Fig. 1B). Among the various clinical parameters, only bone metastasis was positively associated with the expression of Cav-1 in the PPC $(\mathrm{P}=0.021)$ and CRPC 
A

Cav-1
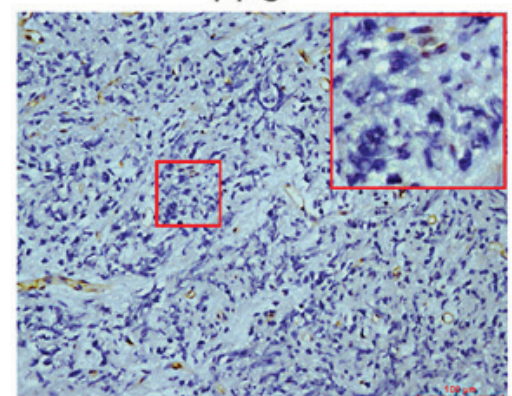

\section{.}
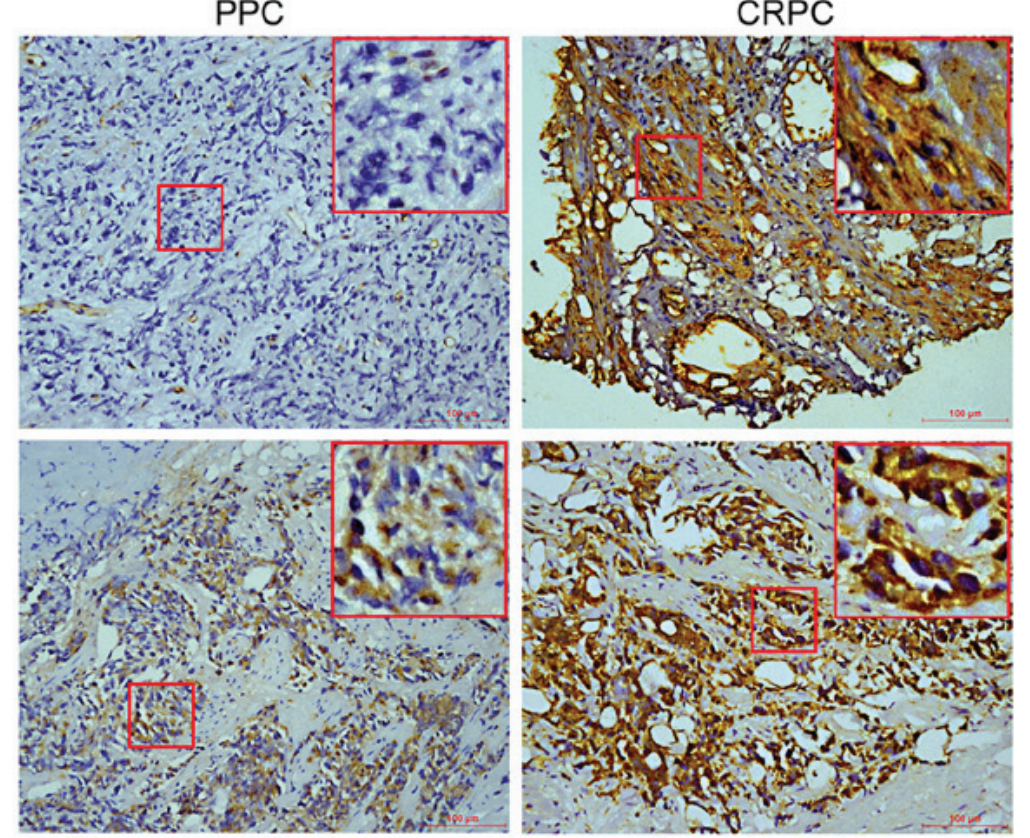

H-Ras

K-Ras
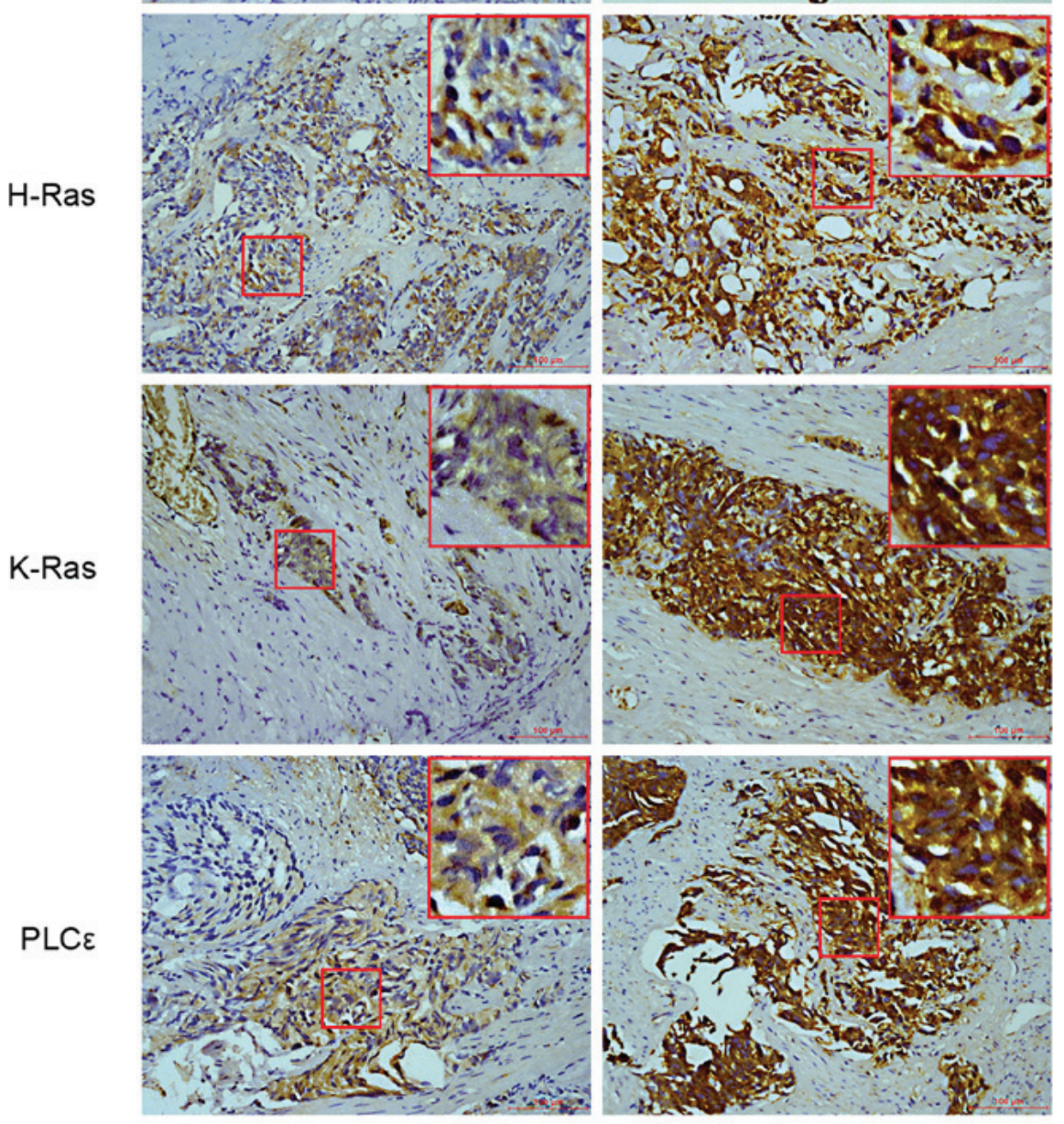

B
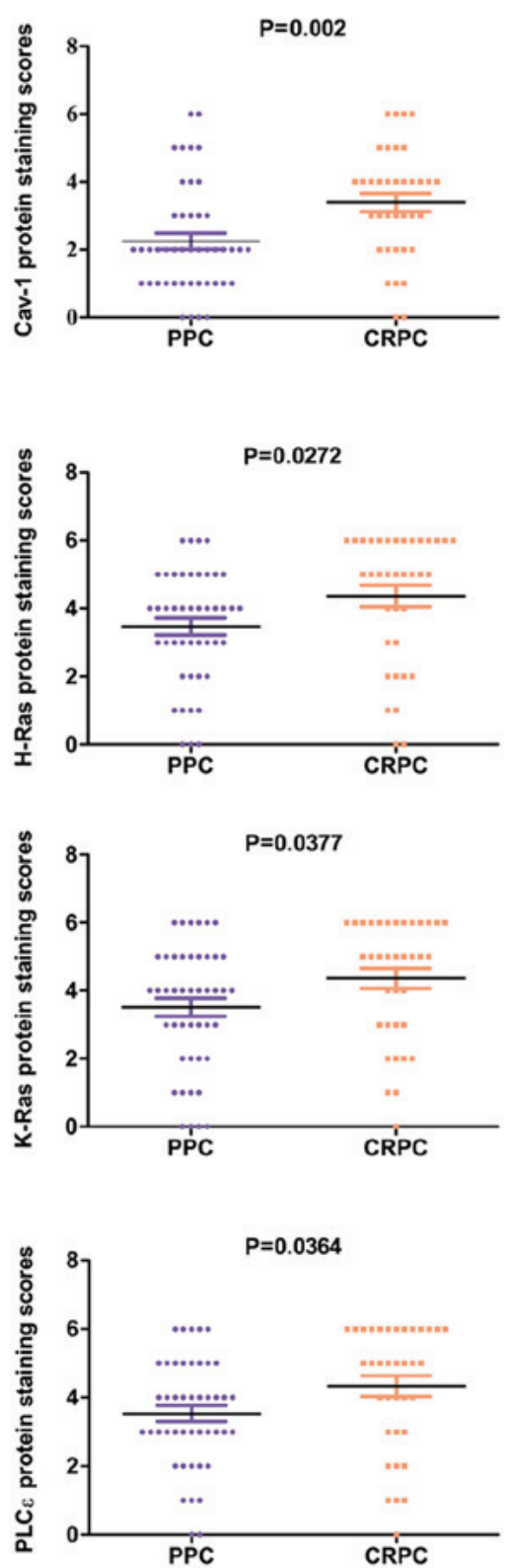

C
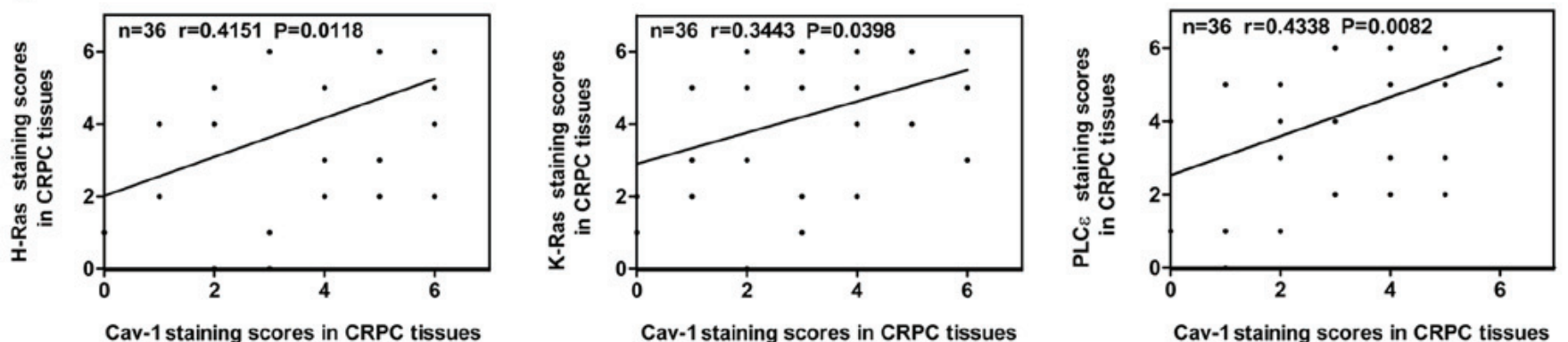

Figure 1. Expression levels of Cav-1, H-Ras, K-Ras and PLC $\varepsilon$ in 45 PPC and 36 CRPC tumor samples. (A) Cav-1, H-Ras, K-Ras and PLC $\varepsilon$ expression in PPC and CRPC was determined by immunochemistry (magnification, x200) (the big red boxes are an enlargement of the area in the small red boxes, enlarged almost 7-fold). (B) Average staining scores for Cav-1, H-Ras, K-Ras and PLC $\varepsilon$ in PPC and CRPC tissues. (C) Correlation curve analysis for Cav-1 staining scores vs. H-Ras, K-Ras and PLCe staining scores in CRPC tissues. PPC, primary prostate cancer; CRPC, castration-resistant prostate cancer; Cav-1, caveolin-1; PLC $\varepsilon$, phosphoinositide-specific phospholipase Ce.

$(\mathrm{P}=0.006)$ tissues, suggesting that Cav-1 overexpression may promote bone metastasis (Table I).
Kaplan-Meier survival analysis revealed that the median recurrence-free survival (RFS) was 36 months 


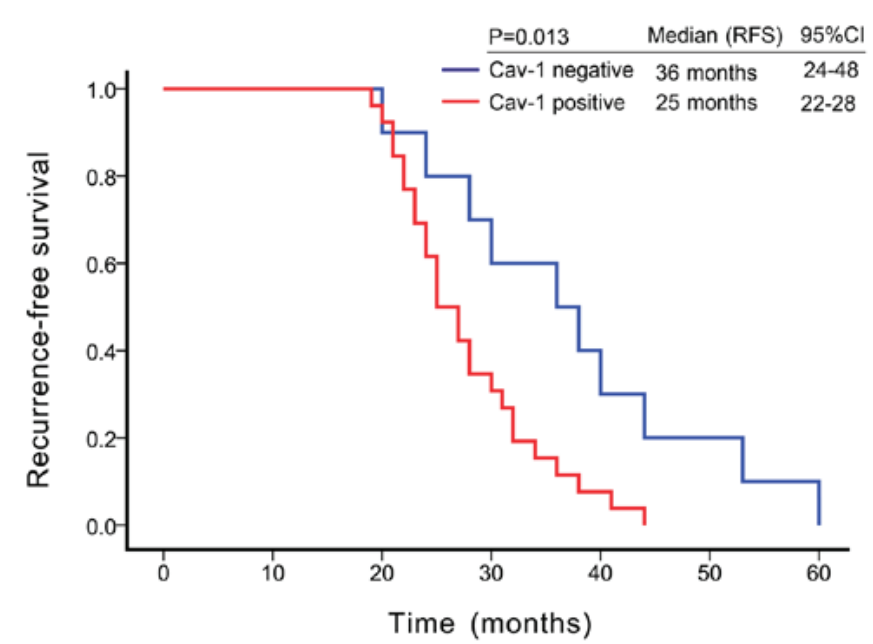

Figure 2. Kaplan-Meier survival analysis of recurrence-free survival in 36 patients with castration-resistant prostate cancer (26 patients with Cav-1-positivite tumors and 10 patients with Cav-1-negative tumors). Cav-1, caveolin-1.

[95\% confidence interval $(\mathrm{CI})=24-48$ months $]$ in patients with Cav-1-negative CRPC, while the median RFS was 25 months $(95 \% \mathrm{CI}=22-28$ months $)$ in Cav-1-positive patients. Cav-1-positive tumor tissues were associated with a shorter RFS in patients with CRPC $(\mathrm{P}=0.013$, log rank test) (Fig. 2). In univariate Cox proportional hazards regression analyses, Cav-1 was found to be significantly associated with recurrence following $\mathrm{ADT}(\mathrm{HR}=2.65,95 \% \mathrm{CI}=1.162-6.029$; $\mathrm{P}=0.02$ ) (Table II), suggesting that Cav-1 is an independent risk
Table II. Univariate Cox proportional hazards regression analysis of Cav-1 for RSF in CRPC.

\begin{tabular}{lcccc}
\hline & \multicolumn{4}{c}{ Univariate analysis } \\
\cline { 2 - 5 } Variable & $\mathrm{n}$ & HR & $95 \%$ CI & P-value \\
\hline Cav-1 & & & & \\
Negative & 10 & & & \\
Positive & 26 & 2.65 & $1.162-6.029$ & $\mathbf{0 . 0 2}^{\mathrm{a}}$ \\
\hline
\end{tabular}

Numbers in bold font indicate statistical significance. ${ }^{\text {aC }}$ Cox proportional hazards regression analysis. Numbers in bold font indicate statistical significance $(\mathrm{P}<0.05)$. Cav-1, caveolin-1; CRPC, castration-resistant prostate cancer; HR, hazard ratios.

factor for the occurrence of CRPC, and that the risk of CRPC occurring in Cav-1-positive patients was 2.65-fold greater than in Cav-1-negative patients.

Expression of Cav-1 in serum may be predictive of CRPC. To gain further insight into the functions of Cav-1 in CRPC, the Cav-1 levels in serum samples from 70 patients with PPC and 56 patients with CRPC were determined by ELISA. Statistical analysis revealed that the mean Cav-1 expression level in the serum of patients with CRPC was higher than in the serum of patients with PPC (CRPC, $1.57 \pm 0.83 \mathrm{ng} / \mathrm{ml}$ vs. PPC, $0.64 \pm 0.25 \mathrm{ng} / \mathrm{ml} ; \mathrm{P}<0.001$ ) (Table III and Fig. $3 \mathrm{~A}$ ). Subsequently, the present study explored whether Cav-1
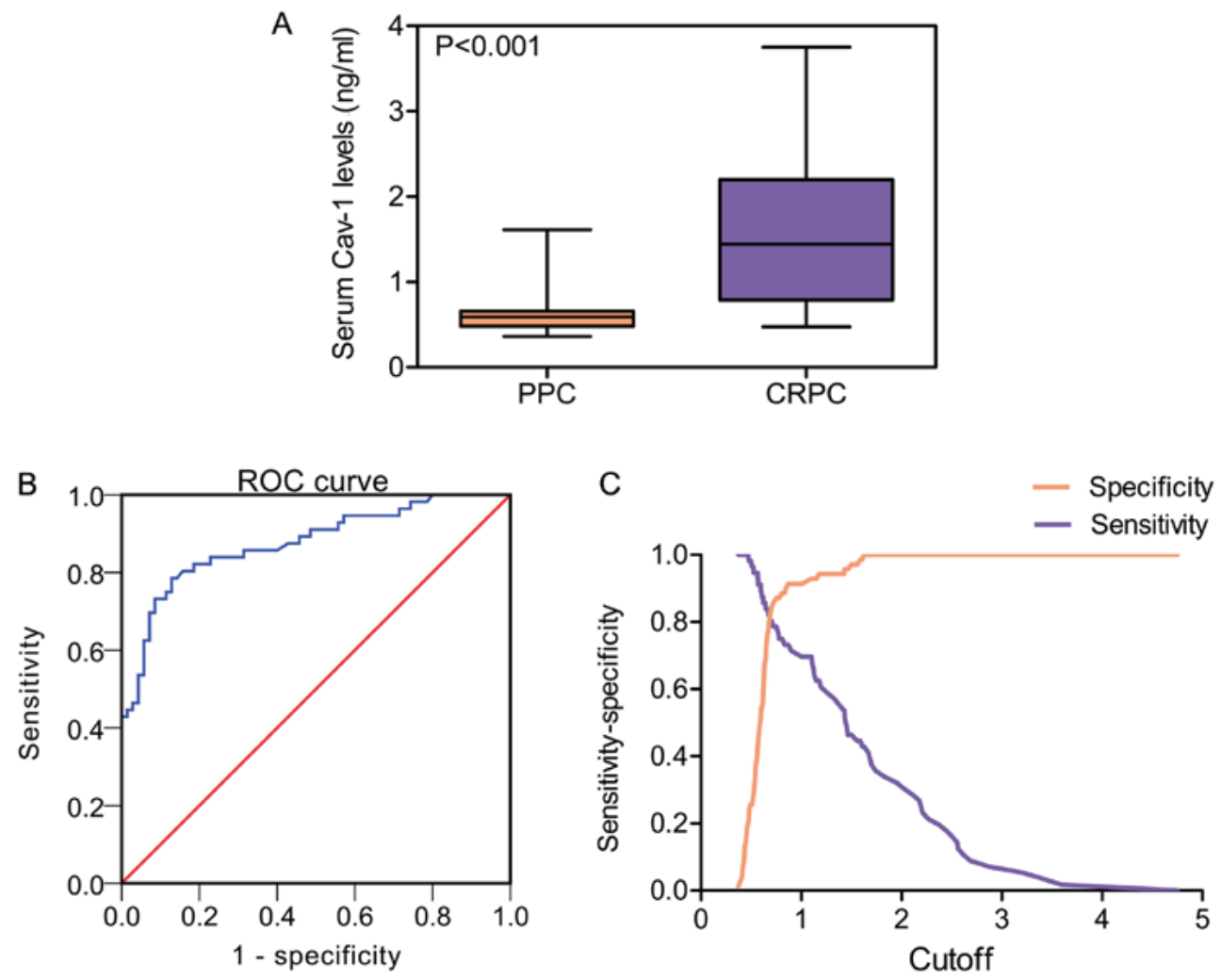

Figure 3. Use of serum Cav-1 expression levels for predicting CRPC. (A) Enzyme-linked immunosorbent assay analysis of serum Cav-1 levels in 70 primary prostate cancer vs. 56 CRPC cases. (B) Receiver operating characteristic curve plot for prediction of CRPC by Cav-1. (C) Sensitivity and specificity associated with different cutoff values for Cav-1 levels for the prediction of CRPC. CRPC, castration-resistant prostate cancer; Cav-1, caveolin-1. 
Table III. Statistical comparison of serum Cav-1 in PPC and CRPC.

\begin{tabular}{lccc}
\hline Group & $\mathrm{n}$ & Mean \pm SD $(\mathrm{ng} / \mathrm{ml})$ & P-value (vs. PPC) \\
\hline PPC & 70 & $0.64 \pm 0.25$ & \\
CRPC & 56 & $1.57 \pm 0.83$ & $\mathbf{P}<\mathbf{0 . 0 0 1}$ \\
\hline
\end{tabular}

P-value is based on the Student's t-test. Numbers in bold font indicate statistical significance $(\mathrm{P}<0.05)$. Cav-1, Caveolin-1; PPC, primary prostate cancer; CRPC, castration-resistant prostate cancer.

Table IV. Association of serum Cav-1 levels with the clinicopathological characteristics of patients with CRPC.

\begin{tabular}{|c|c|c|c|}
\hline & & Cav-1 & \\
\hline Characteristics & No. & Mean \pm SD & P-value \\
\hline Total & 56 & $1.57 \pm 0.83 \mathrm{ng} / \mathrm{ml}$ & \\
\hline \multicolumn{4}{|l|}{ Age (years) } \\
\hline$<60$ & 17 & $1.62 \pm 0.70 \mathrm{ng} / \mathrm{ml}$ & \multirow[t]{2}{*}{$\mathrm{P}=0.788$} \\
\hline$\geq 60$ & 39 & $1.56 \pm 0.89 \mathrm{ng} / \mathrm{ml}$ & \\
\hline \multicolumn{4}{|l|}{ PSA } \\
\hline$<4$ & 12 & $1.46 \pm 0.61 \mathrm{ng} / \mathrm{ml}$ & \multirow[t]{3}{*}{$\mathrm{P}=0.776^{\mathrm{b}}$} \\
\hline $4-10$ & 11 & $1.67 \pm 0.81 \mathrm{ng} / \mathrm{ml}$ & \\
\hline$>10$ & 33 & $1.59 \pm 0.93 \mathrm{ng} / \mathrm{ml}$ & \\
\hline \multicolumn{4}{|l|}{ Metastasis } \\
\hline Yes & 43 & $1.75 \pm 0.83 \mathrm{ng} / \mathrm{ml}$ & \multirow[t]{2}{*}{$P=0.003$} \\
\hline No & 13 & $0.99 \pm 0.55 \mathrm{ng} / \mathrm{ml}$ & \\
\hline
\end{tabular}

${ }^{a}$ t-test for 2 independent variables; ${ }^{b}$ one-way ANOVA was used for multiple comparisons, followed by the Student-Newman-Keuls test as a post hoc test; 'Mann-Whitney test for 2 independent variables. Numbers in bold font indicate statistical significance $(\mathrm{P}<0.05)$. Cav-1, Caveolin-1; PSA, prostate-specific antigen; CRPC, castrationresistant prostate cancer.

can be used as a possible diagnostic factor in CRPC by assessing receiver operating characteristic (ROC) curves. As shown in Fig. 3B, the area under the curve (AUC) was 0.876 (95\% CI $=0.813-0.939)$, suggesting that Cav-1 could be used for the accurate diagnosis of CRPC. The diagnostic properties using different Cav-1 cut-off values are shown in Fig. 3C.

Since different cut-off values result in different values of sensitivity and specificity, the cut-off was set at $0.75 \mathrm{ng} / \mathrm{ml}$, as it maximized the Youden index, resulting in sensitivity and specificity rates of 78.6 and $87.1 \%$, respectively. However, considering that our study population receiving ADT is known to be at high risk of castration resistance, achieving a minimum of $80 \%$ sensitivity and maximizing sensitivity over specificity were deemed desirable. Using this criterion, the optimal cut-off value was set at $0.68 \mathrm{ng} / \mathrm{ml}$, which could improve sensitivity to $82.1 \%$ while maintaining specificity at $80 \%$. Consequently, Cav-1 levels were statistically evaluated with certain clinical parameters in patients with CRPC. The data revealed that an increased Cav-1 expression was positively associated with
Table V. Combination index values for drug-resistant cells treated with combination of simvastatin and bicalutamide or enzalutamide.

\begin{tabular}{lcccc}
\hline & & \multicolumn{3}{c}{ CI value at } \\
\cline { 3 - 5 } Cell line & Drug & EC50 & EC75 & EC90 \\
\hline Bic-R & Sim + Bic & 0.38 & 0.21 & 0.12 \\
En-R & Sim + En & 0.35 & 0.19 & 0.10 \\
\hline
\end{tabular}

CI, combination index; EC, effective concentration; Bic-R, bicalutamide-resistant LNCaP cells; En-R, enzalutamide-resistant LNCaP cells; Sim, simvastatin; Bic, bicalutamide; En, enzaluamide.

tumor metastasis ( $\mathrm{P}=0.003$; Table IV). Taken together, these data suggest that Cav-1 could be used as a potential biomarker to predict metastasis in patients with CRPC.

Cav-1 knockdown suppresses CRPC metastasis. Although we demonstrated shown that the Cav-1 levels were higher in serum and tumor tissues from patients with CRPC than those with PPC, there is little evidence to indicate whether this increase regulates the progression or metastasis of CRPC. To address this question, the present study examined the mRNA and protein expression levels of Cav-1 by RT-qPCR and western blotting, respectively, in an androgen-sensitive $\mathrm{LNCaP}$ cell line and in castration-resistant Bic-R, En-R, PC3 and DU145 cell lines. The protein level of Cav-1 was markedly low in the LNCaP cells, but was considerably higher in the PC3, DU145, Bic-R and En-R cells. At the mRNA level, similar results were obtained (Fig. 4A-C). This finding suggested that Cav-1 expression was increased in the CRPC cells. Subsequently, to determine the relevance of the increased Cav-1 expression on the metastasis of castration-resistant tumors, a Cav-1 knockdown plasmid was constructed and transfected into the PC3 and En-R cells (Fig. 4D and E). The results of western blot analysis revealed that Cav-1 knockdown downregulated the expression levels of factors associated with invasion and migration, such as Snail, MMP2 and MMP9 (Fig. 4F-I). Transwell and wound-healing assays consistently demonstrated that the knockdown of Cav-1 suppressed the invasion and migration of CRPC cells (Fig. 4J-N).

Cav-1 knockdown attenuates the expression of PLCE in DRFs through H-Ras. As stated above, the isoforms of Ras, H-Ras and K-Ras and the downstream gene PLCe were overexpressed in CRPC and exhibited a positive correlation with Cav-1 expression. Therefore, we hypothesized that Cav-1 may regulate Ras signaling in cell membranes and may be associated with CRPC metastasis.

To explore this concept, a series of Cav-1 knockdown experiments were performed and the expression of $\mathrm{H}-\mathrm{Ras}$, K-Ras and PLC $\varepsilon$ in DRFs was examined. H-Ras, K-Ras and PLC $\varepsilon$ were detected in DRFs, which are composed of lipid rafts and caveolae, as confirmed by the presence of Cav-1. The non-classical localization of PLCE was specifically observed in caveolae and rafts by western blot analysis. Additionally, the knockdown of Cav-1 downregulated the expression of 
A

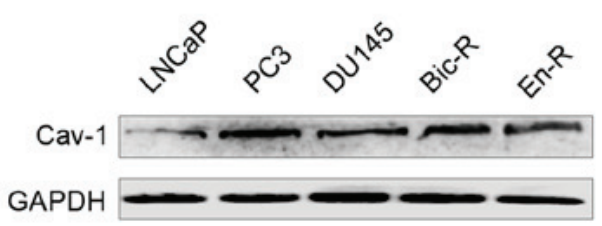

D

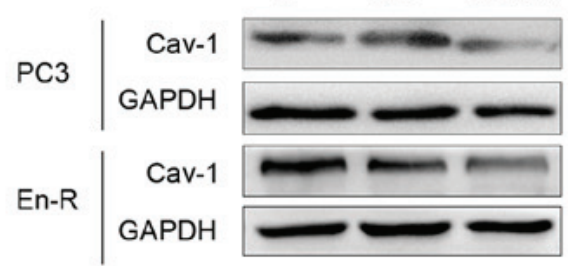

B

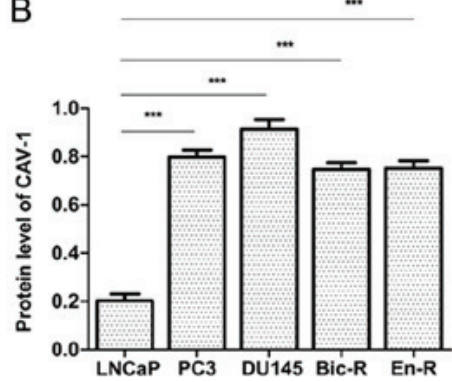

$\mathrm{F}$

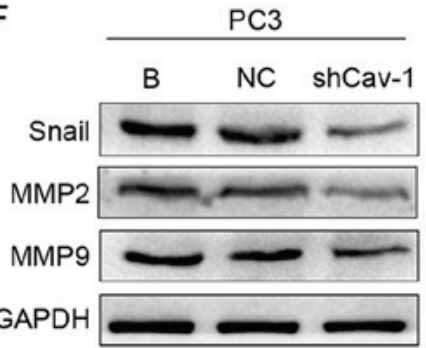

C

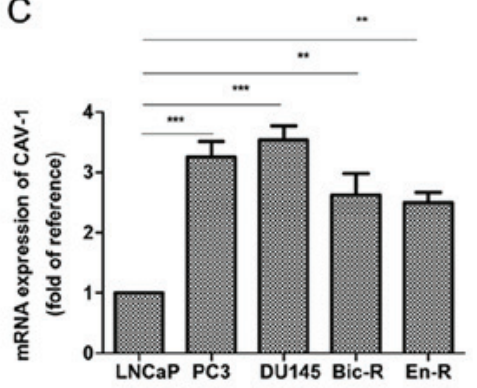

$\mathrm{H}$

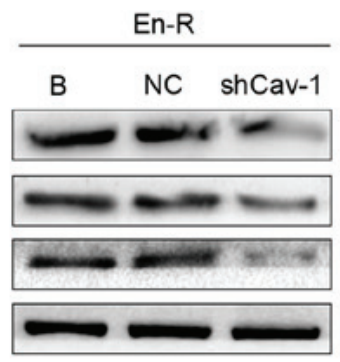

E $\quad \square \quad$ B $\quad$ 口 $\quad$ 口 shCav-1 G
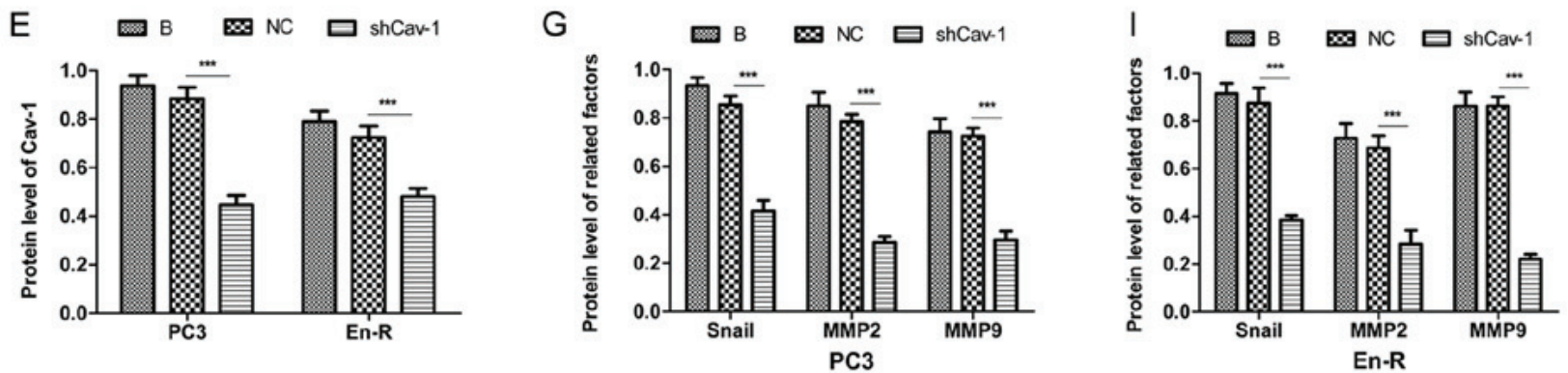

$J$

$\mathrm{M}$
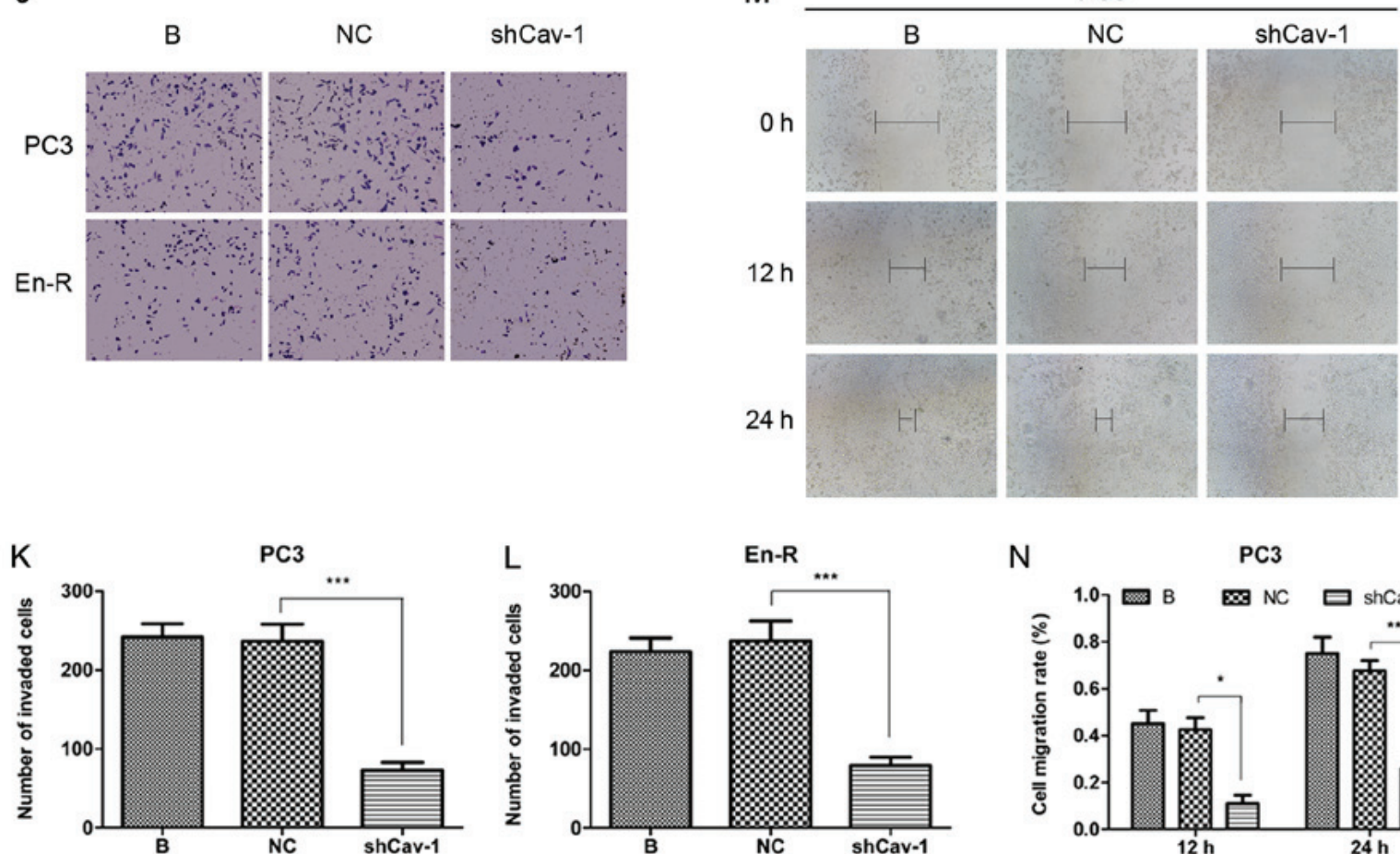

$\mathrm{N}$

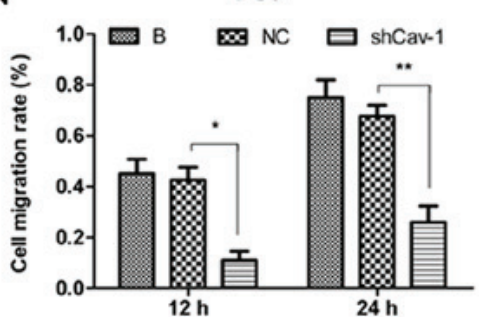

Figure 4. Knockdown of Cav-1 suppresses the metastasis of CRPC. (A-C) The protein and mRNA expression of Cav-1 was upregulated in the PC3, DU145, Bic-R and En-R cell lines vs. the LNCaP cells. (D and E) Knockdown of Cav-1 was performed by transfection of the cells with plasmids containing shRNA targeting Cav-1. (F-N) The B, NC and shCav-1 groups in PC3 and En-R cells were compared. (F-I) The expression of Snail, MMP2 and MMP9 in PC3 and En-R cells was examined by western blot analysis. (J-N) The cell invasive and migratory capacities were evaluated using Transwell and wound-healing assays. Cells were transfected with a negative control or shCav-1 for $72 \mathrm{~h}$. GAPDH served as a loading control. " $\mathrm{P}<0.05$, " $\mathrm{P}<0.01$ and ${ }^{* * * *} \mathrm{P}<0.001$. Bic-R, bicalutamide-resistant LNCaP cells; En-R, enzalutamide-resistant LNCaP cells; B, blank; NC, negative control; sh, small hairpin; shCav-1, Cav-1 knockdown; CRPC, castration-resistant prostate cancer; Cav-1, caveolin-1; MMP, matrix metalloproteinase. 
A

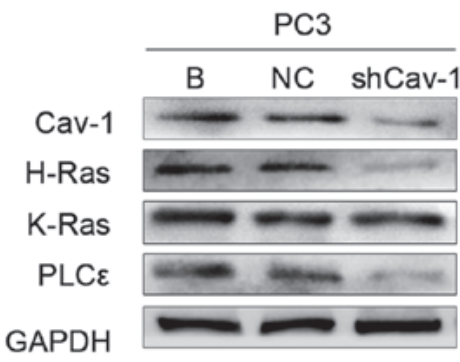

C

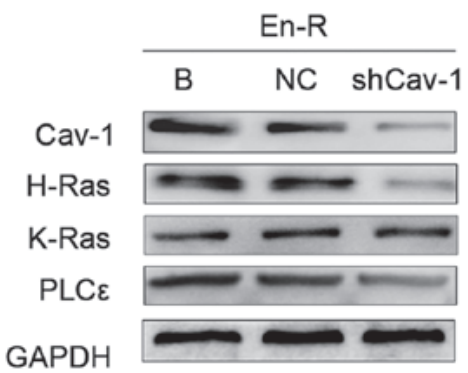

$\mathrm{E}$

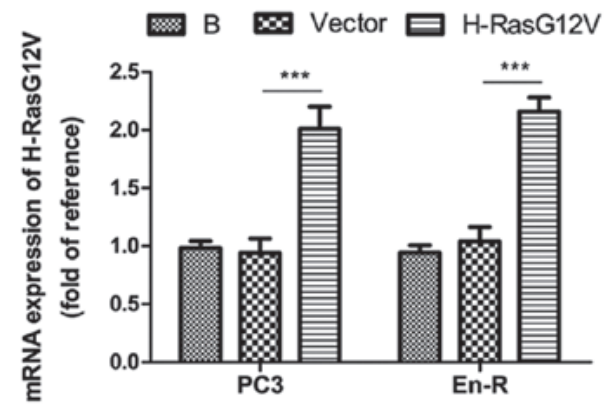

G

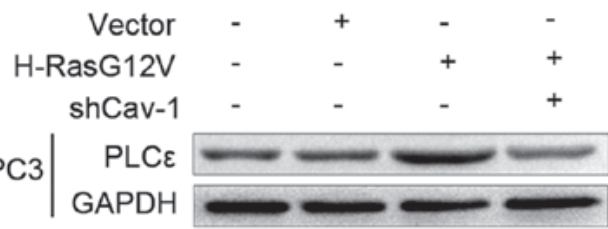

EN-R $\mid \begin{array}{rlc}\text { PLC } \\ \text { GAPDH }\end{array}$
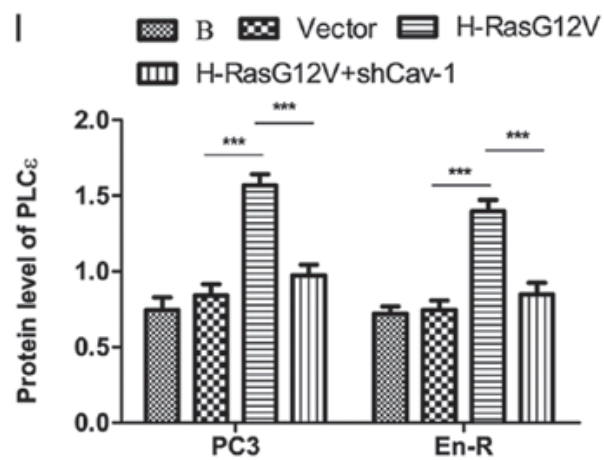
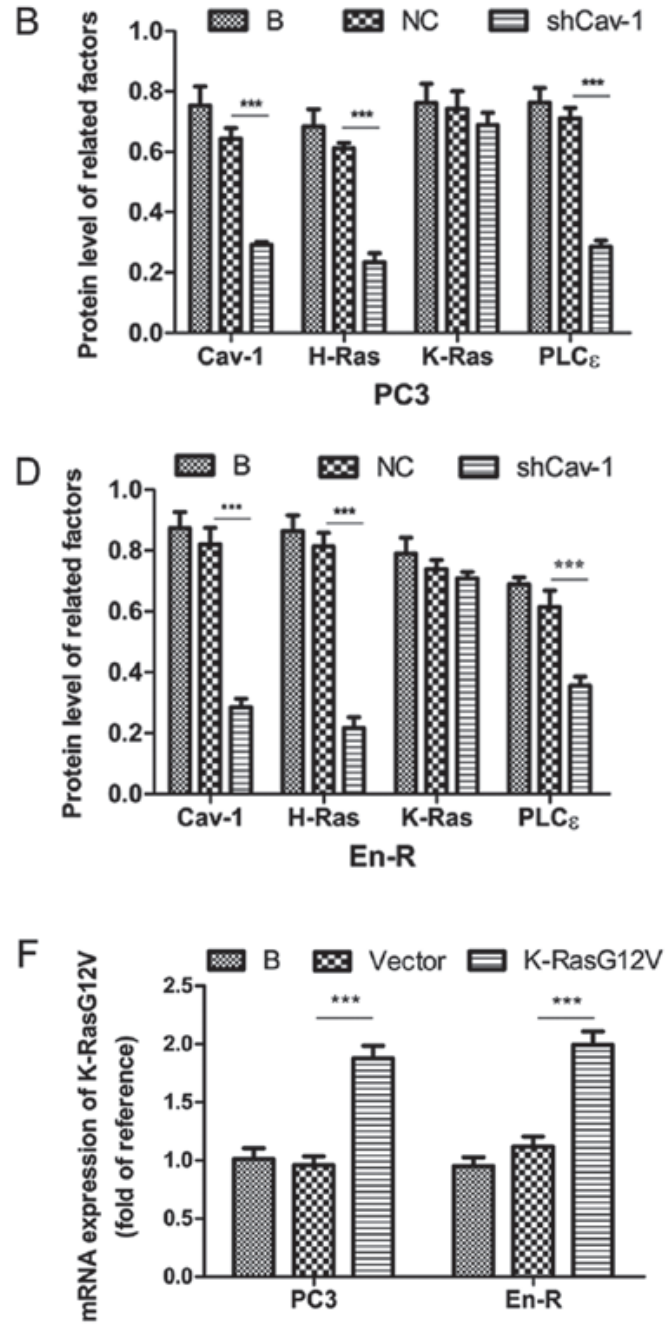

$\mathrm{H}$

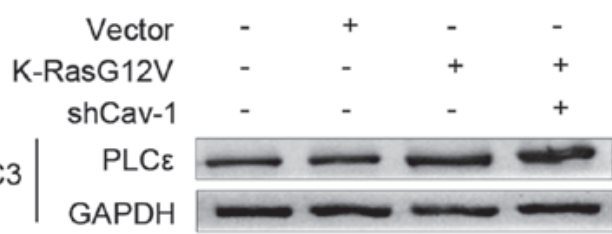

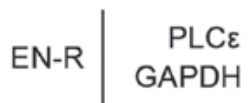

$J$

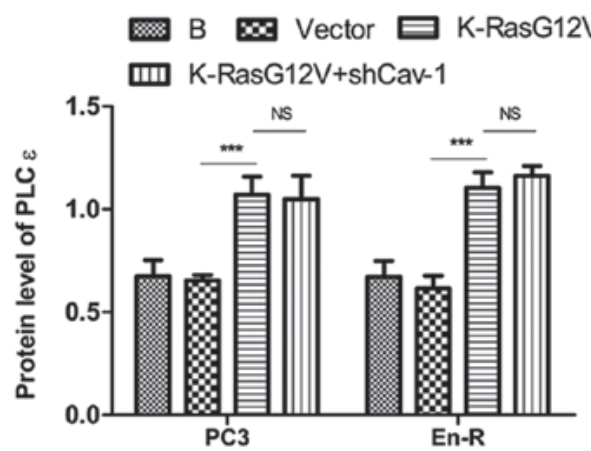

Figure 5. The Ras signaling pathway is regulated by Cav-1. (A-D) Expression level of Cav-1, H-Ras, K-Ras and PLCe in DRFs of PC3 and En-R cells in different groups. (E and F) mRNA expression of verified the successful transfection of H-RasG12V or K-RasG12V plasmids. (G-J) Expression of PLCe in PC3 and En-R cell DRFs by western blot analysis. Cells were treated with activated Ras isoforms, H-RasG12V or K-RasG12V, and with H-RasG12V or K-RasG12V combined with knockdown of Cav-1. ${ }^{* * *} \mathrm{P}<0.001$. NS, not significant. En-R, enzalutamide-resistant LNCaP cells; DRF, detergent-resistant fraction; Cav-1, caveolin-1; PLCE, phosphoinositide-specific phospholipase Ce. B, blank; NC, negative control; sh, small hairpin; shCav-1, Cav-1 knockdown; Vector, empty vector of overexpression plasmid. 
A
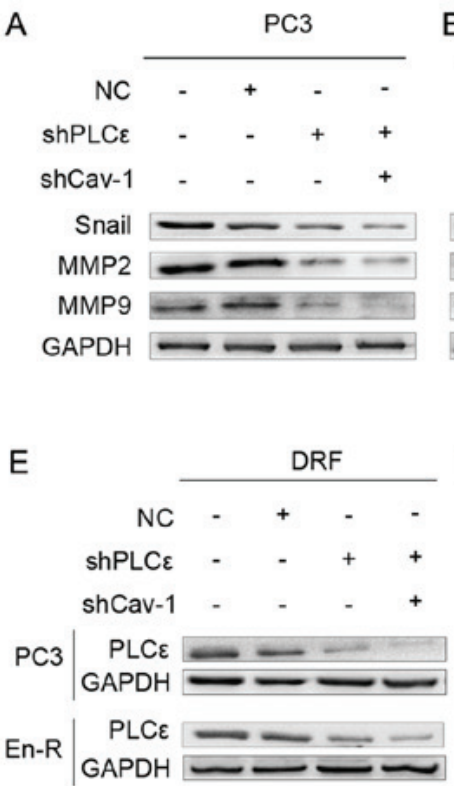

C

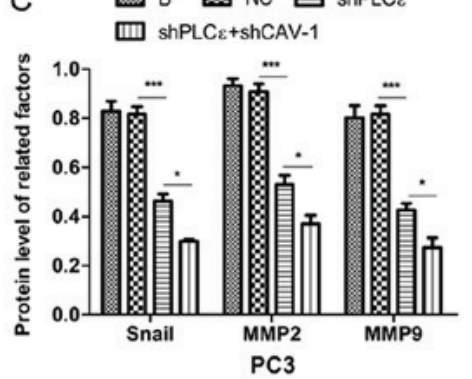

F

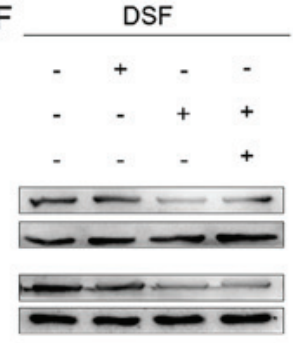

G

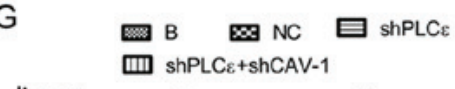

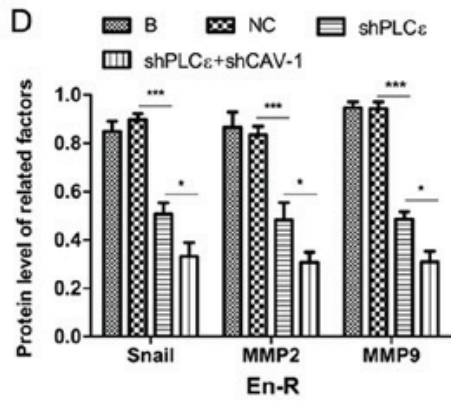

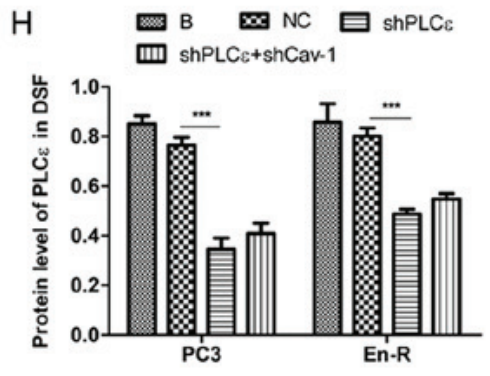

I

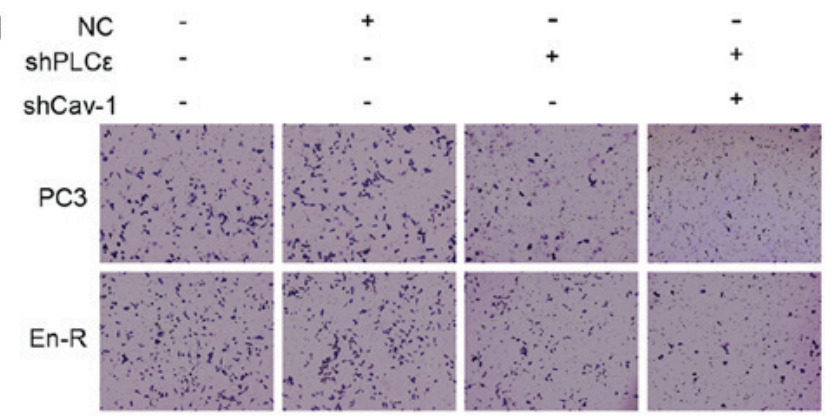

$J$

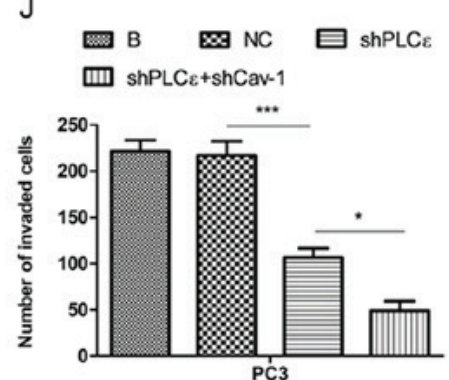

$\mathrm{K}$

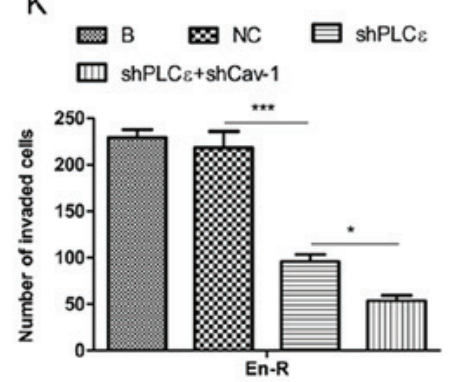

Figure 6. Caveolin-1 regulates protein factors of metastasis via the downregulation of PLC $\varepsilon$ in DRFs. (A-D) Protein expression of Snail, MMP2 and MMP9. (E-H) Western blot analysis of the expression of PLC $\varepsilon$ in DRF and DSF. (I-K) The cell invasive capacities were evaluated among different treatment groups. ${ }^{*} \mathrm{P}<0.05$ and ${ }^{* * *} \mathrm{P}<0.001$. DRF, detergent-resistant lipid-rich membrane fraction; DSF, detergent-soluble fraction; PLC $\varepsilon$, phosphoinositide-specific phospholipase $\mathrm{C} \varepsilon$; MMP, matrix metalloproteinase.

$\mathrm{H}-\mathrm{Ras}$ and $\mathrm{PLC} \varepsilon$, but did not alter the expression of $\mathrm{K}-\mathrm{R}$ as in DRFs (Fig. 5A-D).

To further elucidate the role of Cav-1 in regulating PLCe through H-Ras, the cells were treated with H-RasG12V and K-RasG12V (Fig. 5E and F), which are the activated forms of H-Ras and K-Ras, respectively. The results revealed that H-RasG12V upregulated the expression of PLC $\varepsilon$ in DRFs in the different CRPC cells, and that this upregulation was reversed by the knockdown of Cav-1 (Fig. 5G and I). K-RasG12V also increased the expression of PLCE, although the knockdown of Cav-1 did not reverse this process (Fig. $5 \mathrm{H}$ and $\mathrm{J}$ ). These results suggest that $\mathrm{Cav}-1$ knockdown attenuates the expression of PLCE in the plasma membrane, particularly in lipid rafts, through H-Ras.

Cav-1 knockdown suppresses the metastasis of CRPC through $H$-Ras/PLCE. Our previous study suggested that PLC $\varepsilon$ induced the invasion and migration of bladder cancer cells (21); however, it remains unclear as to whether PLC $\varepsilon$, in particular PLC $\varepsilon$ in DRFs, is responsible for the invasion and migration of prostate cancer. Therefore, in this study, PLC $\varepsilon$ was knocked down using lentiviral transduction particles. As shown in Fig. 6A-D, the knockdown of PLC $\varepsilon$ in PCa cells decreased the expression of factors involved in invasion and migration, such as Snail, MMP2 and MMP9, suggesting that PLCE regulates invasion and migration in CRPC.

To determine whether the process of metastasis is associated with the expression of PLCE in DRFs, PLCE was knocked down in combination with the knockdown of Cav-1. The results revealed that, compared with the knockdown of PLC $\varepsilon$ alone, the concurrent knockdown of Cav-1 downregulated the expression of PLCE only in DRFs and slightly upregulated the expression of PLCE in DSFs (although the difference was not statistically significant) (Fig. 6E-H). Consistently, the knockdown of Cav-1 in combination with the knockdown of PLCe downregulated more effectively the changes in downstream factors of invasion and migration compared with knockdown of PLCE alone (Fig. 6A-D). Using Transwell assays, consistent results were obtained (Fig. 6I-K), suggesting that the knockdown of Cav-1 suppressed invasion and migration in CRPC through the attenuation of the expression of PLCE in plasma membrane caveolae.

Simvastatin abrogates the expression of Cav-1 associated with membrane cholesterol. Murata et al have previously reported that Cav-1 can directly binds cholesterol, and that a threshold level of membrane cholesterol is required for caveolae to form (29). To 


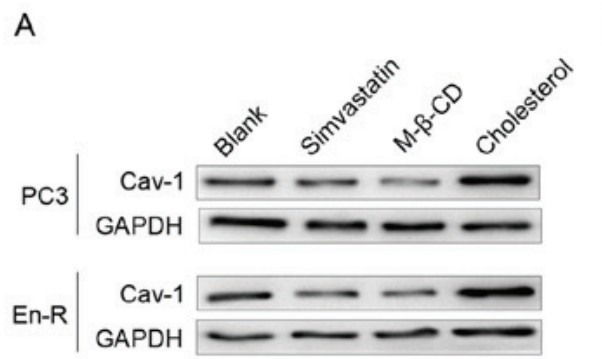

C
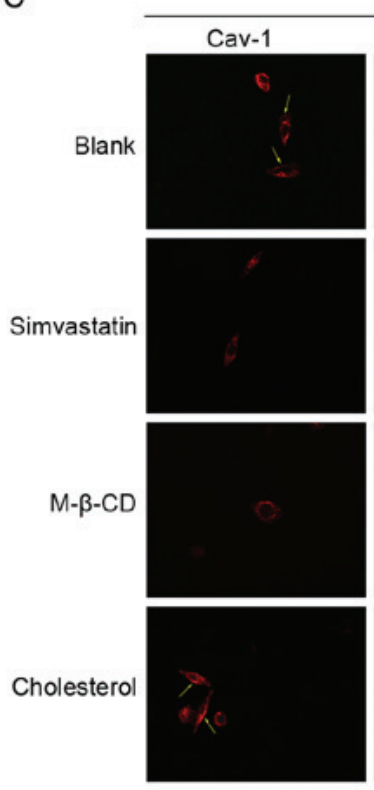

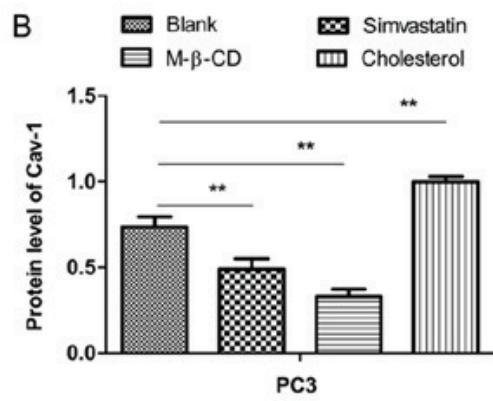

D

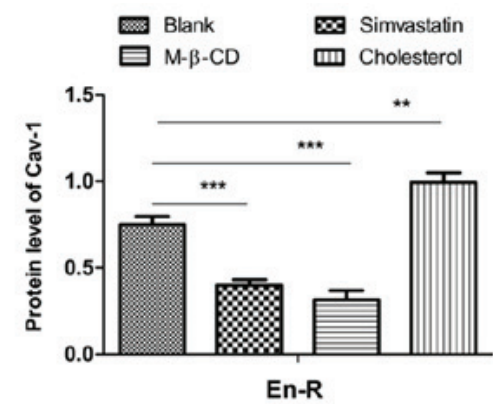

E
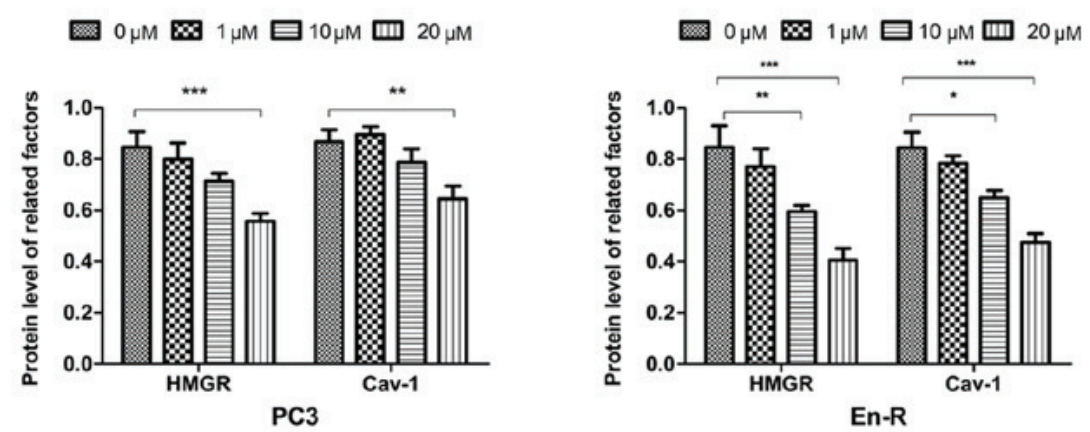

Figure 7. Simvastatin downregulates the expression of Cav-1 via cholesterol de novo synthesis in cells. (A-C) PC 3 and En-R cells were treated with $10 \mu \mathrm{M}$ simvastatin for $24 \mathrm{~h}, 10 \mathrm{mM}$ methyl- $\beta$-cyclodextrin for $1 \mathrm{~h}$ and $10 \mu \mathrm{M}$ cholesterol for $5 \mathrm{~h}$. (A and B) Western blot analysis of the expression of Cav-1 in detergent-resistant lipid-rich membrane fractions. (C) Cav-1 was detected using an immunofluorescence assay; cell nuclei were stained with DAPI (magnification, x200). Arrows mark the Cav-1 expression in membranes. (D and E) PC3 and En-R cells were treated with simvastatin at $0,1,10$ and $20 \mu \mathrm{M}$ for $24 \mathrm{~h}$. Western blot analysis was performed to detect the expression of 3-hydroxy-3-methylglutaryl coenzyme A reductase and Cav-1. ${ }^{*} \mathrm{P}<0.05,{ }^{* * *} \mathrm{P}<0.01$ and ${ }^{* * *} \mathrm{P}<0.001$. En-R, enzalutamide-resistant LNCaP cells; Cav-1, caveolin-1.

delineate whether cholesterol is responsible for the expression of Cav-1, the cells were cultured in serum-free conditions, which removed the effects of exogenous cholesterol, and treated the cells with simvastatin, M- $\beta-C D$ and cholesterol. Simvastatin is an inhibitor of HMGR, which causes the blockade of cholesterol biosynthesis at the rate-limiting step (HMG-CoA conversion to mevalonate) (30). M- $\beta-\mathrm{CD}$ is the most effective agent for stripping cholesterol from the cell membrane. Both drugs can therefore deplete cholesterol through different pathways.

In this study, simvastatin decreased the expression of Cav-1 in DRFs, although the level varied in different cells, similar to what was observed with M- $\beta$-CD. Inversely, cholesterol replenishment resulted in an increased membrane Cav-1 expression compared with the untreated cells (Fig. 7A and B). The immunofluorescence assay revealed similar results (Fig. 7C). Taken together, these results suggested that there was a functional association between free membrane cholesterol and Cav-1 expression in CPRC cells.

To further delineate the association between simvastatin and Cav-1, western blot analysis revealed that $10 \mu \mathrm{M}$ simvastatin decreased the expression of HMGR and Cav-1 in En-R cells, with an even greater suppression when $20 \mu \mathrm{M}$ simvastatin 

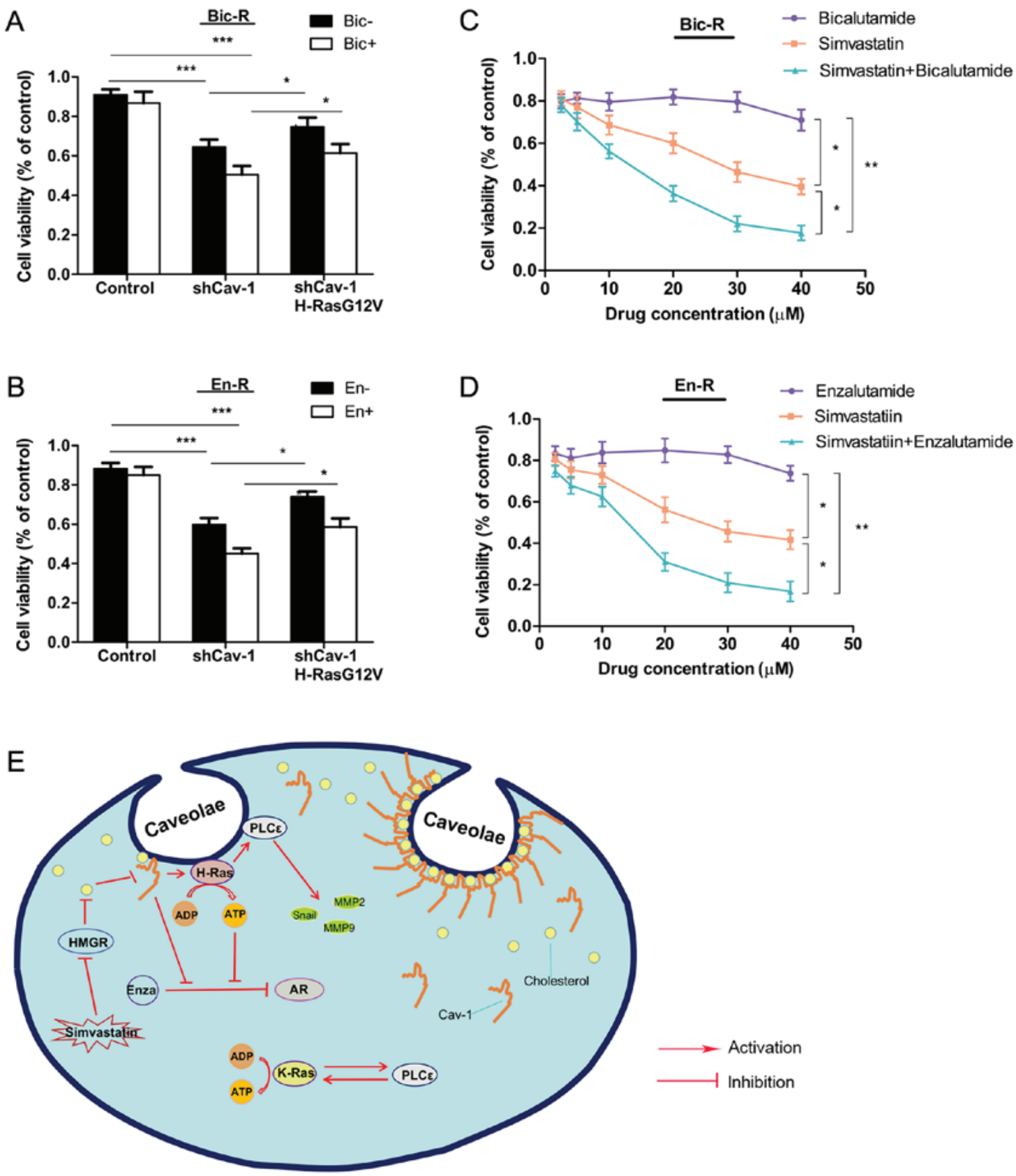

Figure 8. Effects of simvastatin and Cav-1 on androgen receptor antagonist resistance. (A and B) Bic-R and En-R cells were transfected with Cav-1 knockdown plasmids with or without H-RasG12V. After $24 \mathrm{~h}, 10 \mu \mathrm{M}$ of bicalutamide or enzalutamide was applied and further incubated for $48 \mathrm{~h}$, and then cell survival rates were analyzed using CCK- 8 analysis in triplicate. (C and D) Various concentrations of bicalutamide or enzalutamide and simvastatin were applied to Bic-R and En-R cells in a 1:1 ratio. After 48 h, cell survival rates were analyzed using CCK-8 in triplicate. P-values were calculated using one-way ANOVA, followed by the Student-Newman-Keuls test as a post hoc test. ${ }^{*} \mathrm{P}<0.05,{ }^{* *} \mathrm{P}<0.01$ and ${ }^{* * * *} \mathrm{P}<0.001$. (E) Schematic diagram summarizing our findings: Cav-1 upregulates the expression of H-Ras/PLC $\varepsilon$ in caveolae, which can promote the migration, invasion and drug resistance in CRPC. Simvastatin, a 3-hydroxy-3-methylglutaryl coenzyme A reductase inhibitor, can downregulate the expression of Cav-1 in caveolae by blocking cholesterol biosynthesis, which in turn delays the progression of CRPC. Bic-R, bicalutamide-resistant LNCaP cells; En-R, enzalutamide-resistant LNCaP cells; shCav-1, Cav-1 knockdown; sh, small hairpin; Cav-1, caveolin-1; CRPC, castration-resistant prostate cancer.

was used. A statistically significant decrease in the expression of HMGR and Cav-1 also occurred when the PC3 cells were cultured with $20 \mu \mathrm{M}$ simvastatin, but not with $10 \mu \mathrm{M}$ simvastatin (Fig. 7D and E). Taken together, these results indicate that simvastatin can markedly suppress membrane Cav-1 expression through inhibition of de novo cholesterol synthesis in CRPC cells.

Simvastatin enhances the effects of anti-androgenic drugs through Cav-l. To further explore whether Cav-1 reverses the sensitivity of the cells to AR antagonists, Cav-1 was knocked down in Bic-R and En-R cells. Cell proliferation was not suppressed by bicalutamide in the control cells, but was suppressed in the cells in which Cav-1 was knocked down, and was further suppressed in the cells in which Cav-1 was knocked down and treated with bicalutamide. Replenishment with H-RasG12V modestly reversed the suppression of cell proliferation caused by Cav-1 knockdown or by Cav-1 knockdown combined with bicalutamide. The same results were observed with enzalutamide treatment (Fig. 8A and B), 
suggesting that Cav-1 can reverse the sensitivity of cells to AR antagonists partly through H-RasG12V.

Finally, to explore whether simvastatin exerts antitumor effects on CRPC, cell viability was evaluated by a CCK-8 assay in cells treated with various concentrations of simvastatin. In contrast to enzalutamide or bicalutamide treatment, in these drug-resistant cells, increasing concentrations of simvastatin caused a gradual decrease in the viability of CPRC cells, and more prominently when enzalutamide or bicalutamide was combined with simvastatin (Fig. 8C and D). Consistently, simvastatin enhanced the suppressive effect of enzalutamide on the En-R or bicalutamide on Bic-R cells, as indicated by the combination indexes $(\mathrm{CI})<1$. [En-R, $\mathrm{CI}=0.35$ at effective concentration $(\mathrm{EC})$ of 50, 0.19 at $\mathrm{EC}=75$ and 0.10 at $\mathrm{EC}=90$; and Bic-R, $\mathrm{CI}=0.38$ at $\mathrm{EC}=50,0.21$ at $\mathrm{EC}=75$ and 0.12 at $\mathrm{EC}=90]$ (Table V).

\section{Discussion}

Determining the appropriate therapy for CRPC is challenging due to castration-resistant progression and the unavailability of measurable biomarkers or validated surrogate markers. The present study demonstrated that Cav-1 was overexpressed in tissue and serum specimens of patients with CRPC compared to those with PPC, and this was also shown in different PPC and CRPC cell lines. However, various studies have previously observed that the expression of Cav-1 is downregulated in prostate and breast cancer, and Cav-1 has been described as being a tumor-suppressor gene $(31,32)$. Unlike these previous studies, which compared non-malignant with malignant prostate cancer tissue or the expression of Cav-1 in the tumor stroma, this study mainly explored the differential expression of endothelial Cav-1 in CRPC and PPC. Similar to our results, various previous studies have suggested that Cav-1 is upregulated in cancers at the advanced stages, and that the overexpression of Cav-1 is closely associated with aggressive behavior and poor clinical outcomes in various types of cancer (33-38). Burgermeister et al also revealed that Cav-1 was 'Janus-faced' and tissue-specific in cancers of different types and stages, and this conditional functionality was also reflected in its potential tumor-suppressing roles in early disease stages and oncogenic roles in later stages (39). A similar observation has also been documented for hepatocellular carcinoma and melanoma $(40,41)$. In addition, this upregulation of the expression of Cav-1 either in tissue or serum specimens is strongly associated with CRPC metastasis. This persists into the late metastatic stage and may be identified as a signature suggesting early aggressiveness, which provides a guidance for the application of anti-Cav-1 therapy in early-stage disease. In this study, a clear separation of RFS curves was observed in patients with Cav-1-positive vs. Cav-1-negative tumors, suggesting that Cav-1 may be associated with a poor prognosis of patients who received ADT.

Furthermore, ROC analysis and AUC values underscored the enhanced prognostic performance of Cav-1 in evaluating the risk of castration resistance in patients with PPC who received ADT. The determination of serum Cav-1 seems feasible as it is technically simple and less invasive compared with conventional diagnostic indexes that require a tissue biopsy. The limitations of this study include the relatively small number of only Chinese subjects and the fact that the analysis was retrospective. Further studies with additional populations performed in a prospective manner are required.

This study also suggests that, when castration resistance occurs, not only Cav-1, but also H-Ras, K-Ras and PLCe expression is upregulated. However, the findings suggest that Cav-1 may act only upstream of $\mathrm{H}$-Ras and regulate the expression of H-Ras and PLCE in the membrane caveolae. This is slightly less consistent with our results from immunohistochemistry, which revealed that the expression of Cav-1 was also positively associated with K-Ras in patients with CRPC. Supporting our findings, Hancock reported that each Ras isoform has a different lipid anchor and a different hyper-variable flanking region that participates in membrane interactions (42). Therefore, the correlation between Cav-1 and K-Ras may involve other connections, while K-Ras is not directly activated by Cav-1.

However, to date, at least to the best of our knowledge, there are no reports that have elucidated the oncogenic roles of membrane PLCE. Although various studies have shown that Ras proteins are membrane-associated signal transducers and participate in the malignant behavior of numerous human tumors (43-46), studies on different types of tumors have mainly implicated the Ras-mitogen-activated protein kinase (MAPK)/ERK kinase signaling axis as important in cell proliferation and resistance to apoptosis $(19,45,46)$. The findings of this study revealed that Cav-1 increased the metastatic potential in CRPC through the relocation and activation of the H-Ras/PLC $\varepsilon$ kinase cascade in membranes. Similarly, Smrcka et al noted that Ras caused the translocation of PLC $\varepsilon$ from the cytosol to the membrane where it would gain access to the phosphatidylinositol-4,5-bisphosphate substrate, while the Rap GTP-binding protein promotes the translocation of PLCE to perinuclear regions in Cos-7 cells (18). Although membrane targeting may not be the only factor driving activation, translocation from the cytosol to the plasma membrane may, in part, underlie the mechanism involved in the activation of PLCE, which then induces the invasion and migration of CRPC cells.

In the present study, an appropriate strategy to attenuate the progression of CRPC was demonstrated. The knockdown of Cav-1 not only suppressed the metastasis of CRPC but also decreased resistance to AR antagonists in CRPC cells. This finding was supported by the findings of our previous study, which reported that the blocking of PLC $\varepsilon$ reversed AR nuclear translocation (22). However, activated H-Ras mutants can only partly reverse sensitization to anti-androgenic drugs that has been augmented by Cav-1 knockdown. Further studies are warranted to determine whether other signaling cascades are involved in this process.

Previous studies have demonstrated that numerous cholesterol synthesis enzymes, including sterol-regulatory element binding proteins (SREBPs) and its downstream targets, such as HMG-CoA synthase, exhibit an increased expression at the mRNA and protein level in CRPC disease following AR antagonist treatment (47-50). Han et al also reported the increased expression of AR-V7, which may be the result of more intensive androgen-deprivation, such as abiraterone or enzalutamide treatment, and is associated with therapeutic resistance, potentially restored the lipid biosynthetic pathways and led to intracellular cholesterol accumulation (51). Notably, the expression of Cav-1 in the 
plasma membrane was regulated by cholesterol, whether exogenously supplied or through endogenous de novo biosynthesis. At the same time, as a significant factor associated with cholesterol homeostasis (11), upregulated mRNA and protein levels of Cav-1 may represent a metabolic feedback of this pathway and a protective mechanism with which to limit cellular cholesterol accumulation in these cells, although it is activated alongside other carcinogenic mechanisms. In this context, the administration of AR antagonists followed by simvastatin can enhance the anticancer efficacy of enzalutamide or bicalutamide. Simvastatin is used as first-line clinical treatment for hypercholesterolemia due to its low price and few side-effects; however, its use in the treatment of cancer has rarely been reported. The present study has shed light onto the role of simvastatin in inhibiting resistance of CRPC to AR antagonists. Therefore, our findings may provide a novel treatment strategy for clinicians with which to delay the progression of CRPC. Furthermore, advising patients to follow a low-cholesterol diet may be an additional method to rationally reduce the risk of CRPC.

In conclusion, and to the best of our knowledge, the present study explored for the first time the effects of membrane Cav-1/H-Ras/PLC $\varepsilon$ signaling on the metastasis and drug resistance of CRPC. Cav-1 appears to be a promising predictive biomarker of CRPC that may be used to identify patients requiring more intensive treatment and as a putative candidate therapeutic target. Simvastatin was identified as an inhibitor of the development of castration resistance and a factor in delaying the progression of resistance to AR antagonists (Fig. 8E). These findings provide data for the appropriate design of other trials of drug resistance in CRPC, in particular chemotherapeutic drug resistance, as well as longitudinal trials in vivo that could validate this treatment modality for clinical use.

\section{Acknowledgements}

The authors would like to thank The Department of Urinary, The First Affiliated Hospitals of Chongqing Medical University, China, for providing technical assistance and specimen collection.

\section{Funding}

The study was supported by a grant from the Natural Science Foundation of China (no. 81802543).

\section{Availability of data and materials}

All data generated or analyzed during this study are included in this published article.

\section{Authors' contributions}

YG, CL and LL designed the experiments. YG, TL, LM, ZD, $\mathrm{ZQ}, \mathrm{XW}$ and MY collected the specimens and analyzed the clinical data. YG, WS, HC, LN, carried out the experiments. YG wrote the manuscript. ZQ, CL and XW provided technical support of this research project and supervised the progress of the experiments. YG, YF and JF analyzed the statistical data. YG, LL and TL assembled and installed the figures. All authors have read and approved the final manuscript.

\section{Ethics approval and consent to participate}

This study was approved by the Ethics Committee of Chongqing Medical University. Informed consent was obtained from the patients or their family members who agreed to the use of their samples in this study.

\section{Patient consent for publication}

Not applicable.

\section{Competing interests}

The authors declare that they have no competing interests.

\section{References}

1. Watson PA, Arora VK and Sawyers CL: Emerging mechanisms of resistance to androgen receptor inhibitors in prostate cancer. Nat Rev Cancer 15: 701-711, 2015.

2. Wang C, Peng G, Huang H, Liu F, Kong DP, Dong KQ, Dai LH, Zhou $\mathrm{Z}$ and Wang KJ, et al: Blocking the feedback loop between neuroendocrine differentiation and macrophages improves the therapeutic effects of enzalutamide (MDV3100) on prostate cancer. Clin Cancer Res 24: 708-723, 2018.

3. Zhu G, Yan W, He HC, Bi XC, Han ZD, Dai QS, Ye YK, Liang YX Wang $\mathrm{J}$ and Zhong W: Inhibition of proliferation, invasion, and migration of prostate cancer cells by downregulating elongation factor-1alpha expression. Mol Med 15: 363-370, 2009.

4. Shiota M, Fujimoto N, Imada K, Yokomizo A, Itsumi M, Takeuchi A, Kuruma H, Inokuchi J, Tatsugami K, Uchiumi T, et al: Potential role for YB-1 in castration-resistant prostate cancer and resistance to enzalutamide through the androgen receptor $\mathrm{V} 7$. J Natl Cancer Inst: Feb 8, 108, 2016 (Epub ahead of print). doi: 10.1093/jnci/djw005.

5. de Bono JS, Chowdhury S, Feyerabend S, Elliott T, Grande E, Melhem-Bertrandt A, Baron B, Hirmand M, Werbrouck P and Fizazi K: Antitumour activity and safety of enzalutamide in patients with metastatic castration-resistant prostate cancer previously treated with abiraterone acetate plus prednisone for $\geq 24$ weeks in Europe. Eur Urol 74: 37-45, 2018.

6. Penson DF, Armstrong AJ, Concepcion R, Agarwal N, Olsson C, Karsh L, Dunshee C, Wang F, Wu K, Krivoshik A, et al: Enzalutamide versus bicalutamide in castration-resistant prostate cancer: The STRIVE Trial. J Clin Oncol 34: 2098-2106, 2016.

7. Antonarakis ES, Lu C, Wang H, Luber B, Nakazawa M, Roeser JC, Chen Y, Mohammad TA, Chen Y, Fedor HL, et al: AR-V7 and resistance to enzalutamide and abiraterone in prostate cancer. N Engl J Med 371: 1028-1038, 2014.

8. Efstathiou E, Titus M, Wen S, Hoang A, Karlou M, Ashe R, Tu SM, Aparicio A, Troncoso P, Mohler J, et al: Molecular characterization of enzalutamide-treated bone metastatic castration-resistant prostate cancer. Eur Urol 67: 53-60, 2015.

9. Crona DJ, Milowsky MI and Whang YE: Androgen receptor targeting drugs in castration-resistant prostate cancer and mechanisms of resistance. Clin Pharmacol Ther 98: 582-589, 2015.

10. Coffey $\mathrm{K}$ and Robson $\mathrm{CN}$ : Regulation of the androgen receptor by post-translational modifications. J Endocrinol 215: 221-237, 2012.

11. Couet J, Belanger MM, Roussel E and Drolet MC: Cell biology of caveolae and caveolin. Adv Drug Deliv Rev 49: 223-235, 2001.

12. Sotgia F, Martinez-Outschoorn UE, Howell A, Pestell RG, Pavlides S and Lisanti MP: Caveolin-1 and cancer metabolism in the tumor microenvironment: Markers, models, and mechanisms. Annu Rev Pathol 7: 423-467, 2012.

13. Chatterjee M, Ben-Josef E, Thomas DG, Morgan MA, Zalupski MM, Khan G, Andrew Robinson C, Griffith KA, Chen CS, Ludwig T, et al: Caveolin-1 is associated with tumor progression and confers a multi-modality resistance phenotype in pancreatic cancer. Sci Rep 5: 10867, 2015. 
14. Wang Y, Roche O, Xu C, Moriyama EH, Heir P, Chung J, Roos FC Chen Y, Finak G, Milosevic M, et al: Hypoxia promotes ligandindependent EGF receptor signaling via hypoxia-inducible factor-mediated upregulation of caveolin-1. Proc Natl Acad Sci USA 109: 4892-4897, 2012.

15. Nwosu ZC, Ebert MP, Dooley S and Meyer C: Caveolin-1 in the regulation of cell metabolism: A cancer perspective. Mol Cancer 15: 71, 2016.

16. Quest AF, Gutierrez-Pajares JL and Torres VA: Caveolin-1: An ambiguous partner in cell signalling and cancer. J Cell Mol Med 12: 1130-1150, 2008.

17. Hehlgans S and Cordes N: Caveolin-1: An essential modulator of cancer cell radio-and chemoresistance. Am J Cancer Res 1: 521-530, 2011.

18. Smrcka AV, Brown JH and Holz GG: Role of phospholipase $\mathrm{C} \varepsilon$ in physiological phosphoinositide signaling networks. Cell Signal 24: 1333-1343, 2012.

19. Samatar AA and Poulikakos PI: Targeting RAS-ERK signalling in cancer: Promises and challenges. Nat Rev Drug Discov 13: 928-942, 2014.

20. Zhang RY, Du WQ, Zhang YC, Zheng JN and Pei DS: PLCe signaling in cancer. J Cancer Res Clin Oncol 142: 715-722, 2016.

21. Du HF, Ou LP, Yang X, Song XD, Fan YR, Tan B, Luo CL and

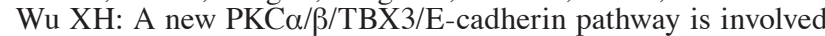
in PLCE-regulated invasion and migration in human bladder cancer cells. Cell Signal 26: 580-593, 2014

22. Wang Y, Wu X, Ou L, Yang X, Wang X, Tang M, Chen E and Luo C: PLCE knockdown inhibits prostate cancer cell proliferation via suppression of Notch signalling and nuclear translocation of the androgen receptor. Cancer Lett 362: 61-69, 2015.

23. Cornford P, Bellmunt J, Bolla M, Briers E, De Santis M, Gross T, Henry AM, Joniau S, Lam TB, Mason MD, et al: EAU-ESTRO-SIOG guidelines on prostate cancer. Part II: Treatment of relapsing, metastatic, and castration-resistant prostate cancer. Eur Urol 71: 630-642, 2017.

24. Du Z, Li L, Sun W, Wang X, Zhang Y, Chen Z, Yuan M, Quan Z, Liu N, Hao Y, et al: HepaCAM inhibits the malignant behavior of castration-resistant prostate cancer cells by downregulating Notch signaling and PF-3084014 (a $\gamma$-secretase inhibitor) partly reverses the resistance of refractory prostate cancer to docetaxel and enzalutamide in vitro. Int J Oncol 53: 99-112, 2018.

25. Livak KJ and Schmittgen TD: Analysis of relative gene expression data using real-time quantitative PCR and the 2(-Delta Delta $\mathrm{C}(\mathrm{T})$ ) method. Methods 25: 402-408, 2001.

26. Kortum RL, Fernandez MR, Costanzo-Garvey DL, Johnson HJ, Fisher KW, Volle DJ and Lewis RE: Caveolin-1 is required for kinase suppressor of Ras 1 (KSR1)-mediated extracellular signalregulated kinase $1 / 2$ activation, $\mathrm{H}-\mathrm{RasV} 12$-induced senescence, and transformation. Mol Cell Biol 34: 3461-3472, 2014.

27. Lingwood D and Simons K: Detergent resistance as a tool in membrane research. Nat Protoc 2: 2159-2165, 2007.

28. Quan Z,He Y,Luo C, Xia Y,Zhao Y,Liu N and Wu X: Interleukin 6 induces cell proliferation of clear cell renal cell carcinoma by suppressing hepaCAM via the STAT3-dependent up-regulation of DNMT1 or DNMT3b. Cell Signal 32: 48-58, 2017.

29. Murata M, Peränen J, Schreiner R, Wieland F, Kurzchalia TV and Simons K: VIP21/caveolin is a cholesterol-binding protein. Proc Natl Acad Sci USA 92: 10339-10343, 1995.

30. Mullen PJ, Yu R, Longo J, Archer MC and Penn LZ: The interplay between cell signalling and the mevalonate pathway in cancer. Nat Rev Cancer 16: 718-731, 2016.

31. Yang B, Bhusari S, Kueck J, Weeratunga P, Wagner J, Leverson G, Huang W and Jarrard DF: Methylation profiling defines an extensive field defect in histologically normal prostate tissues associated with prostate cancer. Neoplasia 15: 399-408, 2013.

32. Sotgia F, Rui H, Bonuccelli G, Mercier I, Pestell RG and Lisanti MP: Caveolin-1, mammary stem cells, and estrogendependent breast cancers. Cancer Res 66: 10647-10651, 2006.

33. Tahir SA, Yang G, Ebara S, Timme TL, Satoh T, Li L, Goltsov A, Ittmann M, Morrisett JD and Thompson TC: Secreted caveolin-1 stimulates cell survival/clonal growth and contributes to metastasis in androgen-insensitive prostate cancer. Cancer Res 61: 3882-3885, 2001.

34. Timme TL, Goltsov A, Tahir S, Li L, Wang J, Ren C, Johnston RN and Thompson TC: Caveolin-1 is regulated by c-myc and suppresses c-myc-induced apoptosis. Oncogene 19: 3256-3265, 2000.
35. Senetta R, Stella G, Pozzi E, Sturli N, Massi D and Cassoni P: Caveolin-1 as a promoter of tumour spreading: When, how, where and why. J Cell Mol Med 17: 325-336, 2013

36. Mi L, Zhu F, Yang X, Lu J, Zheng Y, Zhao Q, Wen X, Lu A, Wang M, Zheng M, et al: The metastatic suppressor NDRG1 inhibits EMT, migration and invasion through interaction and promotion of caveolin-1 ubiquitylation in human colorectal cancer cells. Oncogene 36: 4323-4335, 2017.

37. Yamaguchi H, Takeo Y, Yoshida S, Kouchi Z, Nakamura Y and Fukami K: Lipid rafts and caveolin-1 are required for invadopodia formation and extracellular matrix degradation by human breast cancer cells. Cancer Res 69: 8594-8602, 2009.

38. Senetta R, Trevisan E, Rudà R, Maldi E, Molinaro L, Lefranc F, Chiusa L, Lanotte M, Soffietti R and Cassoni P: Caveolin 1 expression independently predicts shorter survival in oligodendrogliomas. J Neuropathol Exp Neurol 68: 425-431, 2009.

39. Burgermeister E, Liscovitch M, Röcken C, Schmid RM and Ebert MP: Caveats of caveolin-1 in cancer progression. Cancer Lett 268: 187-201, 2008.

40. Tse EY, Ko FC, Tung EK, Chan LK, Lee TK, Ngan ES, Man K, Wong AS, Ng IO and Yam JW: Caveolin-1 overexpression is associated with hepatocellular carcinoma tumourigenesis and metastasis. J Pathol 226: 645-653, 2012.

41. Pandey V, Vijayakumar MV, Ajay AK, Malvi P and Bhat MK: Diet-induced obesity increases melanoma progression: Involvement of Cav-1 and FASN. Int J Cancer 130: 497-508, 2012.

42. Hancock JF: Ras proteins: Different signals from different locations. Nat Rev Mol Cell Biol 4: 373-384, 2003.

43. Bivona TG and Philips MR: Ras pathway signaling on endomembranes. Curr Opin Cell Biol 15: 136-142, 2003.

44. Castellano E, Molina-Arcas M, Krygowska AA, East P, Warne P, Nicol A and Downward J: RAS signalling through PI3-kinase controls cell migration via modulation of Reelin expression. Nat Commun 7: 11245, 2016.

45. Okada T, Sinha S, Esposito I, Schiavon G, López-Lago MA, Su W, Pratilas CA, Abele C, Hernandez JM, Ohara M, et al: The Rho GTPase Rnd1 suppresses mammary tumorigenesis and EMT by restraining Ras-MAPK signalling. Nat Cell Biol 17: 81-94, 2015.

46. Mazur PK, Reynoird N, Khatri P, Jansen PW, Wilkinson AW, Liu S, Barbash O, Van Aller GS, Huddleston M, Dhanak D, et al: SMYD3 links lysine methylation of MAP3K2 to Ras-driven cancer. Nature 510: 283-287, 2014.

47. Leon CG, Locke JA, Adomat HH, Etinger SL, Twiddy AL, Neumann RD, Nelson CC, Guns ES and Wasan KM: Alterations in cholesterol regulation contribute to the production of intratumoral androgens during progression to castration-resistant prostate cancer in a mouse xenograft model. Prostate 70 : 390-400, 2010

48. Yuan X, Cai C, Chen S, Chen S, Yu Z and Balk SP: Androgen receptor functions in castration-resistant prostate cancer and mechanisms of resistance to new agents targeting the androgen axis. Oncogene 33: 2815-2825, 2014.

49. Holzbeierlein J, Lal P, LaTulippe E, Smith A, Satagopan J, Zhang L, Ryan C, Smith S, Scher H, Scardino P, et al: Gene expression analysis of human prostate carcinoma during hormonal therapy identifies androgen-responsive genes and mechanisms of therapy resistance. Am J Pathol 164: 217-227, 2004.

50. Ettinger SL, Sobel R, Whitmore TG, Akbari M, Bradley DR, Gleave ME and Nelson CC: Dysregulation of sterol response element-binding proteins and downstream effectors in prostate cancer during progression to androgen independence. Cancer Res 64: 2212-2221, 2004.

51. Han W, Gao S, Barrett D, Ahmed M, Han D, Macoska JA, $\mathrm{He} \mathrm{HH}$ and Cai C: Reactivation of androgen receptor-regulated lipid biosynthesis drives the progression of castration-resistant prostate cancer. Oncogene 37: 710-721, 2018.

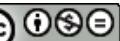

This work is licensed under a Creative Commons Attribution-NonCommercial-NoDerivatives 4.0 International (CC BY-NC-ND 4.0) License. 